\title{
Impact of COVID-19 on the United States economy and the policy response
}

\section{Introduction}

The outbreak of the coronavirus disease (COVID-19) pandemic has upended the global and United States economies, exacting a large human toll and shutting down major economic sectors. While there is significant uncertainty about United States economic growth prospects, the impact of the pandemic is severe. The record-long United States economic expansion came to an end as a result of the COVID-19 pandemic, with forecasts of a deep recession in 2020 . The outlook remains highly uncertain, as it is difficult to gauge the social and economic impact of the pandemic, which will depend on the success of containing the outbreak and the measures to restart economic activity.

The economic policy response to the COVID-19 pandemic has been substantial and immediate Three stimulus packages were approved by the United States Congress in March to address the impact on households and businesses. New legislation was also approved in April and June to improve the effectiveness of the programmes included in the previous three fiscal packages. The United States Federal Reserve cut interest rates to the zero lower bound, offered unlimited quantitative easing and deployed old and new policy tools aimed at keeping financial markets functioning

\section{The record-long United States economic expansion comes to an end ${ }^{1}$}

A severe recession is expected in 2020 owing to the impact of the pandemic. The Federal Reserve's median projections of 10 June point to a 6.5\% decline in GDP in 2020 (with forecasts ranging from $-10 \%$ to $-4.2 \%$ ), a significantly larger contraction than in 2009 (-2.5\%). The pandemic interrupted more than a decade of economic growth -128 consecutive months, from June 2009 to February 2020 - the longest United States expansion on record, although it was less vigorous than in previous cycles (see figure 1).

The effects of COVID-19 and the containment measures were already visible in the final estimate for the first quarter of 2020 (a contraction of 5\%) and in employment and factory output numbers. The advance estimate for second-quarter growth in gross domestic product (GDP) shows a contraction of 32.9\%. The pandemic has led to companies going bankrupt, a decline in private investment, reduced integration into value chains, and erosion of productive capabilities and human capital. The duration and intensity of the economic downturn is uncertain. Also uncertain is whether there will be enduring damage and what kind of recovery will occur once containment measures have been relaxed.

\section{Introduction}

I. The record-long United States economic expansion comes to an end

II. Collapse in employment

III. Slump in industrial production and retail sales

IV. Financial markets were hit hard and fast

V. Disrupted trade flows and supply chains

VI. Strong impact on migration

VII. United States economic policy response: strong and prompt

VIII. Longer-term challenges

Bibliography
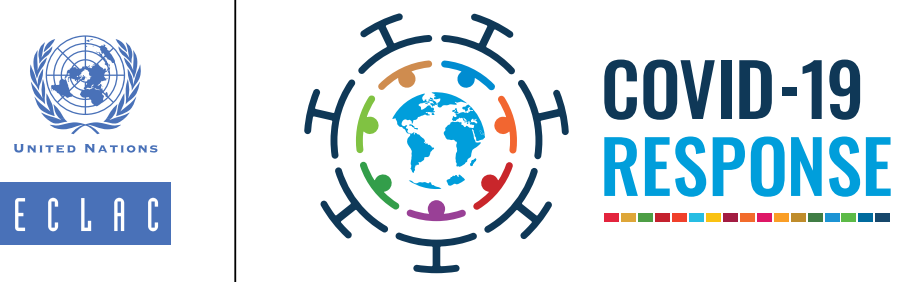
Figure 1

The United States: economic expansions, selected periods between February 1961 and February 2020

(Number of months and percentages of GDP)

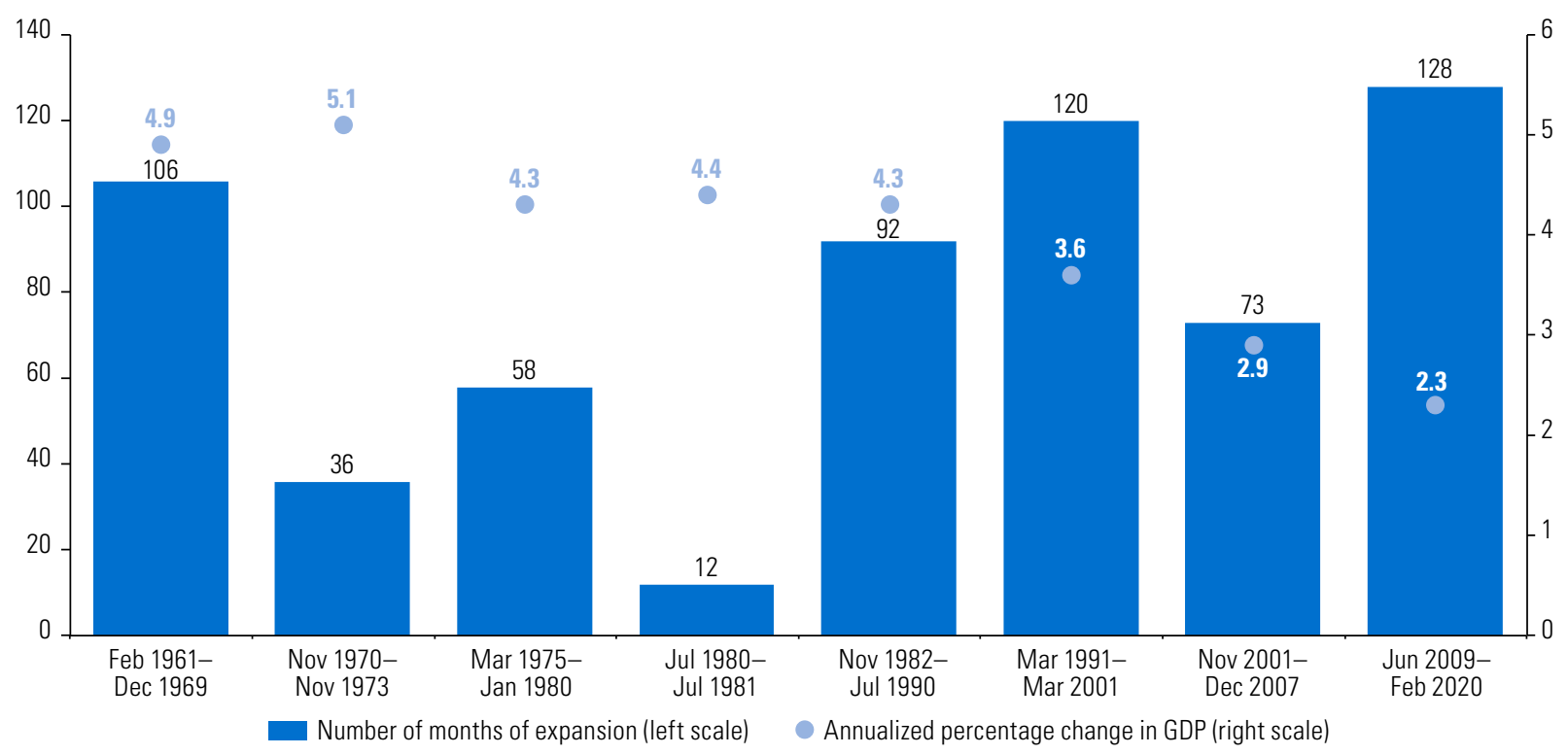

Source: Economic Commission for Latin America and the Caribbean (ECLAC), on the basis of data from the National Bureau of Economic Research (NBER) and the Bureau of Economic Analysis (BEA) of the United States Department of Commerce.

\section{Collapse in employment}

The collapse in employment is of an unprecedented magnitude and seems likely to rival or exceed that of any recession in the last 150 years (Rogoff, 2020). In the 18 weeks from the week ending on 21 March to the week ending on 18 July, a total of 52.7 million people filed for unemployment insurance benefits, shattering the previous record. Although new applications for unemployment benefits have trended down since the pandemic-related lockdowns triggered a surge in claims at the end of March, weekly jobless claims were still close to 1.5 million at the end of the third week of July (see figure 2). Unemployment claims levelled out in June and in the first two weeks of July, suggesting new layoffs were largely being offset by companies hiring and recalling of workers, as states continued to reopen their economies. But joblessness remains at historically high levels. ${ }^{3}$

The longest stretch of job creation in United States history, 113 consecutive months, came to an abrupt halt in March 2020, when 870,000 jobs were lost as a result of the pandemic. In April, the United States economy lost close to 21 million jobs, by far the largest drop on record and more than double the cumulative loss during the 2008-2009 global financial crisis. The unemployment rate jumped to $14.7 \%$, up from $4.4 \%$ in March and the 50 -year low of $3.5 \%$ registered in February (see figure 3 ).

Unemployment benefits have been expanded to those who were previously ineligible for such aid, including self-employed and gig-economy workers. About 10 million workers were receiving these benefits in late May, according to the Labor Department, which are accounted for separately from the regular unemployment insurance program. 
Figure 2

The United States: initial unemployment claims filed weekly, 21 December 2019-18 July 2020

(Number of claims)

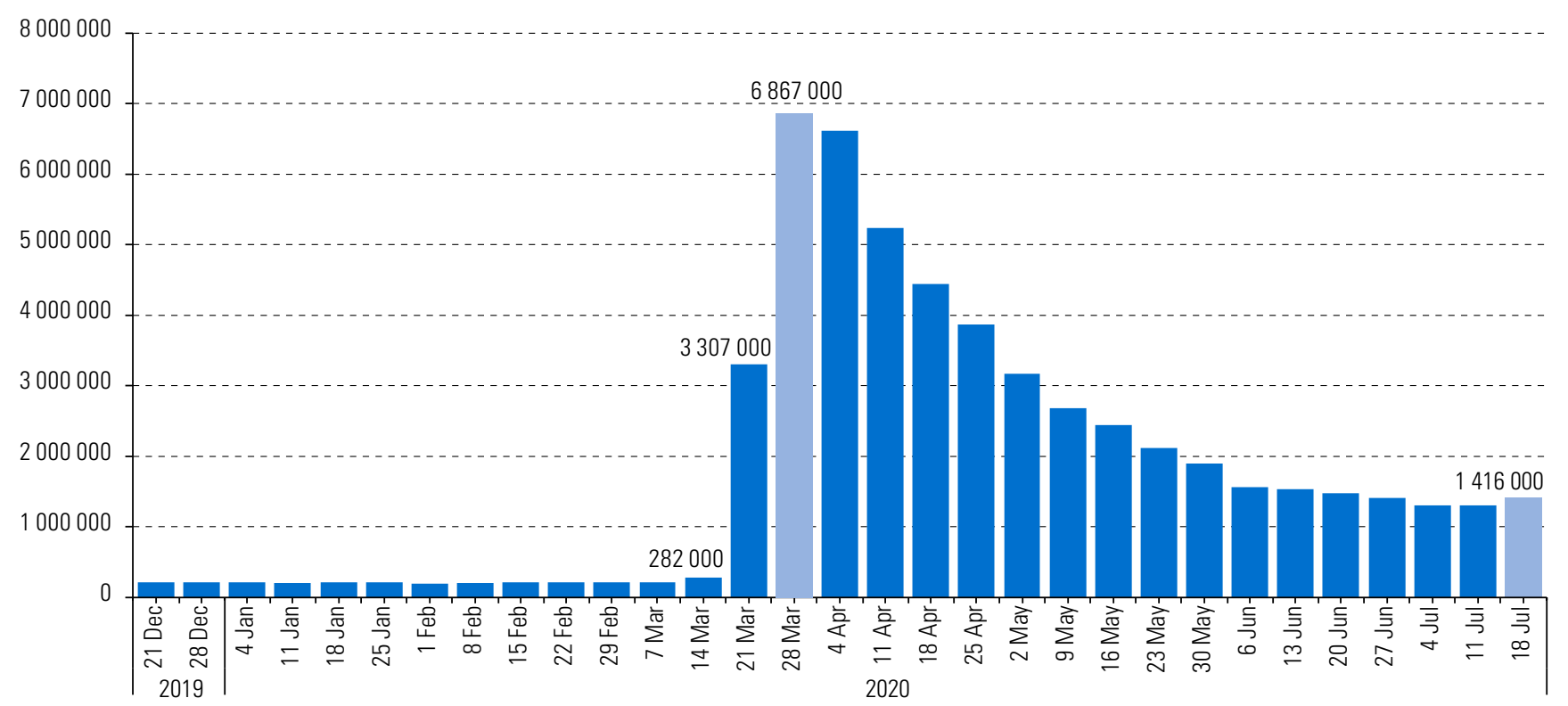

Source: Economic Commission for Latin America and the Caribbean (ECLAC), on the basis of data from Department of Labor, "Unemployment insurance weekly claims report" [online] https://fred.stlouisfed.org/series/ICSA, and the Federal Reserve Bank of St. Louis (FRED).

Figure 3

The United States: average monthly job creation and unemployment rate, January-June 2020

(Millions of jobs and percentages)

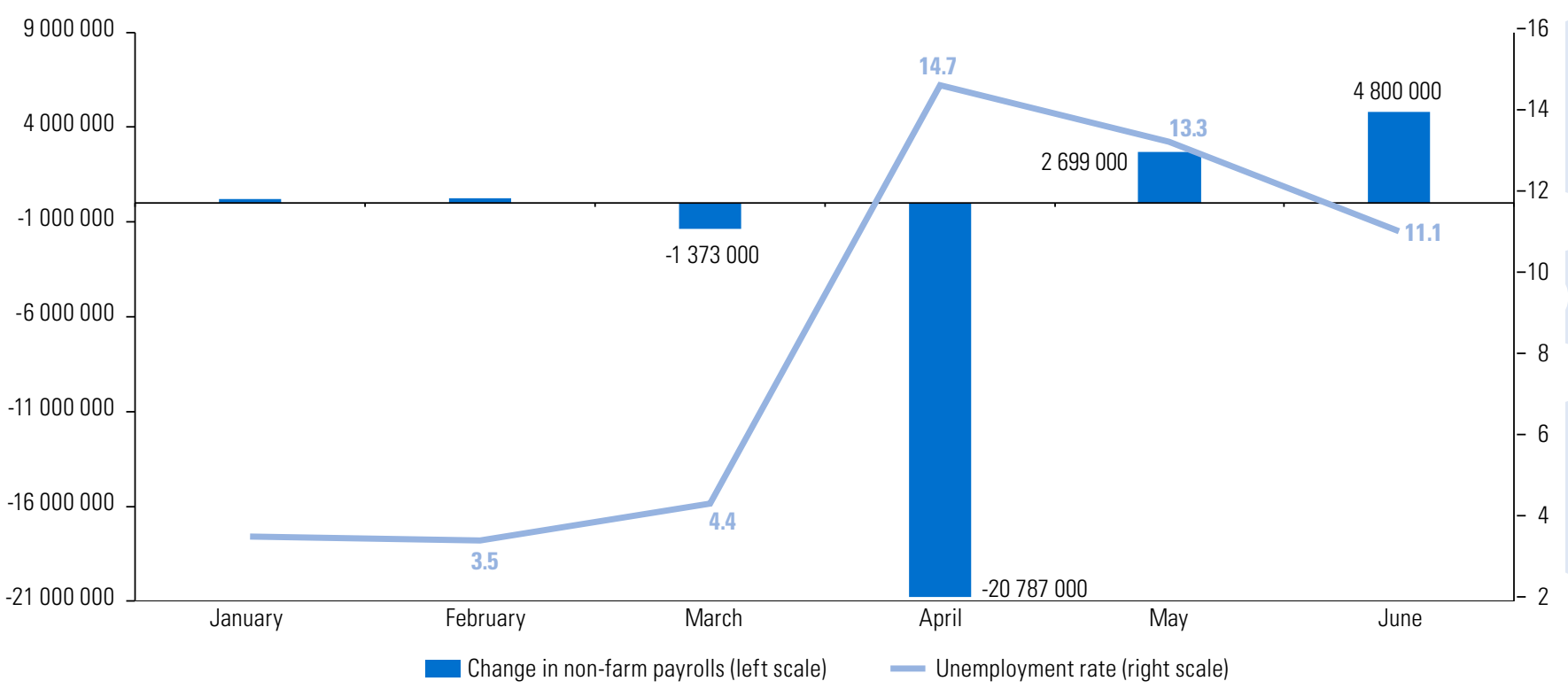

Source: Economic Commission for Latin America and the Caribbean (ECLAC), on the basis of data from the United States Bureau of Labor Statistics (BLS). 
Unemployment data suggest that Hispanics, African Americans and low-wage workers in the restaurant and retail sectors have been the hardest hit. The unemployment rate in April jumped to a record 18.9\% for Hispanics, 16.7\% for African Americans, 14.5\% for Asians and $14.2 \%$ for whites. The unemployment rate was higher among women than among men in all groups (BLS, 2020a).

With the reopening of several states in May, hundreds of thousands of workers returned to jobs in restaurants, health care and construction. As a result, some 2.5 million jobs were created in May and 4.8 million in June, surges that were also partly due to the fiscal policy response and its support to small businesses. The unemployment rate dropped to $13.3 \%$ in May ${ }^{4}$ and to $11.1 \%$ in June. In June, the unemployment rate declined to $16.1 \%$ for Hispanics, to $14.5 \%$ for African Americans, $13.8 \%$ for Asians and $10.1 \%$ for whites. For the most part, the unemployment rate remained higher among women than men (BLS, 2020b and 2020c).

Age and education are also factors, with younger and blue-collar workers, as well as those without college degrees, more likely to have lost their jobs. In April and June, the unemployment rates among people over 25 years of age who have not completed high school stood at $21.2 \%$ and $16.6 \%$, respectively, and at $8.4 \%$ and $6.9 \%$, respectively, for those with a bachelor's degree or higher. Among workers between 16 and 19 years of age, the unemployment rate was 31.9\% in April and $23.2 \%$ in June, compared to $13.1 \%$ and $9.7 \%$, respectively, among those aged 25 years or over.

Sectoral analysis of the effects of the pandemic shows that the services sector suffered an unprecedentedly large blow. About 37.3\% of the job losses in April occurred in the leisure and hospitality industries, but there were also notable declines in education and health services (12.4\%), professional and business services (10.4\%), and the retail trade (10.3\%) (see figure 4). These industries were affected immediately and directly by the pandemiccontainment and physical distancing measures, which included travel restrictions, bans on dine-in service at restaurants, and the closure of bars and other entertainment venues, implemented by states across the country. Together, these sectors accounted for over $31 \%$ of the value added to the economy before the pandemic, according to data from the United States Bureau of Labor Statistics (BLS, 2020d). There were also job losses in the manufacturing sector (6.5\%), as containment measures and supply chain constraints curbed factory output, and in construction (4.8\%).

In May and June, the leisure and hospitality industries, which had suffered the largest losses in March and April, posted the most job gains. Over one fifth of the population is directly employed in retail and hospitality, including stores, bars and restaurants, and the tourism and entertainment industries; this means that more than 32 million people work in sectors that saw widespread closures and layoffs as a result of the COVID-19 pandemic. The repercussions have been widespread, from households, to local economies and municipal budgets, as rents, wages and sales taxes have gone unpaid.

State and local governments shed 980,000 jobs in April and 585,000 jobs in May. Since February, they have cut a total of 1.5 million jobs, an $8 \%$ decline that is twice that seen during and after the 2008-2009 recession. The impact of the pandemic on state and local economies and municipal budgets is a matter of concern, as is avoiding a more permanent breakdown of labour relationships between employers and employees in the wake of job cuts in the private sector. This might require additional government support to address state and local governments' pandemic-induced budget problems, and to help businesses retain as much of their payroll as possible.

The Employment Situation news release issued by the United States Bureau of Labor Statistics (BLS, 2020b) for May included an unusual note which states that "if the workers who were recorded as employed but absent from work due to 'other reasons' (over and above the number absent for other reasons in a typical May) had been classified as unemployed on temporary layoff, the overall unemployment rate would have been about 3 percentage points higher" than the recorded official rate of $13.3 \%$. These potential errors also affected the monthly reports for March and April, reflecting the difficulties posed by the unprecedented impact of the pandemic on employment. However, both the official and corrected May unemployment rates showed improvement compared with figures for April. 
Figure 4

The United States: employment change by industry, April, May and June 2020

(Seasonally adjusted figures, in thousands)

\section{A. April 2020}

Leisure and hospitality

Education and health services

Professional and business services

Retail trade

Manufacturing

Other services

Construction

Transportation and warehousing

Wholesale trade

Financial activities

Information

Mining and logging

Utilities

Government

\section{B. May 2020}

\section{June 2020}

Leisure and hospitality

Construction

Education and health services

Retail trade

Other services

Manufacturing

Professional and business services

Financial activities

Wholesale trade

Utilities

Transportation and warehousing

Mining and logging

Information

Government

$$
-1000
$$
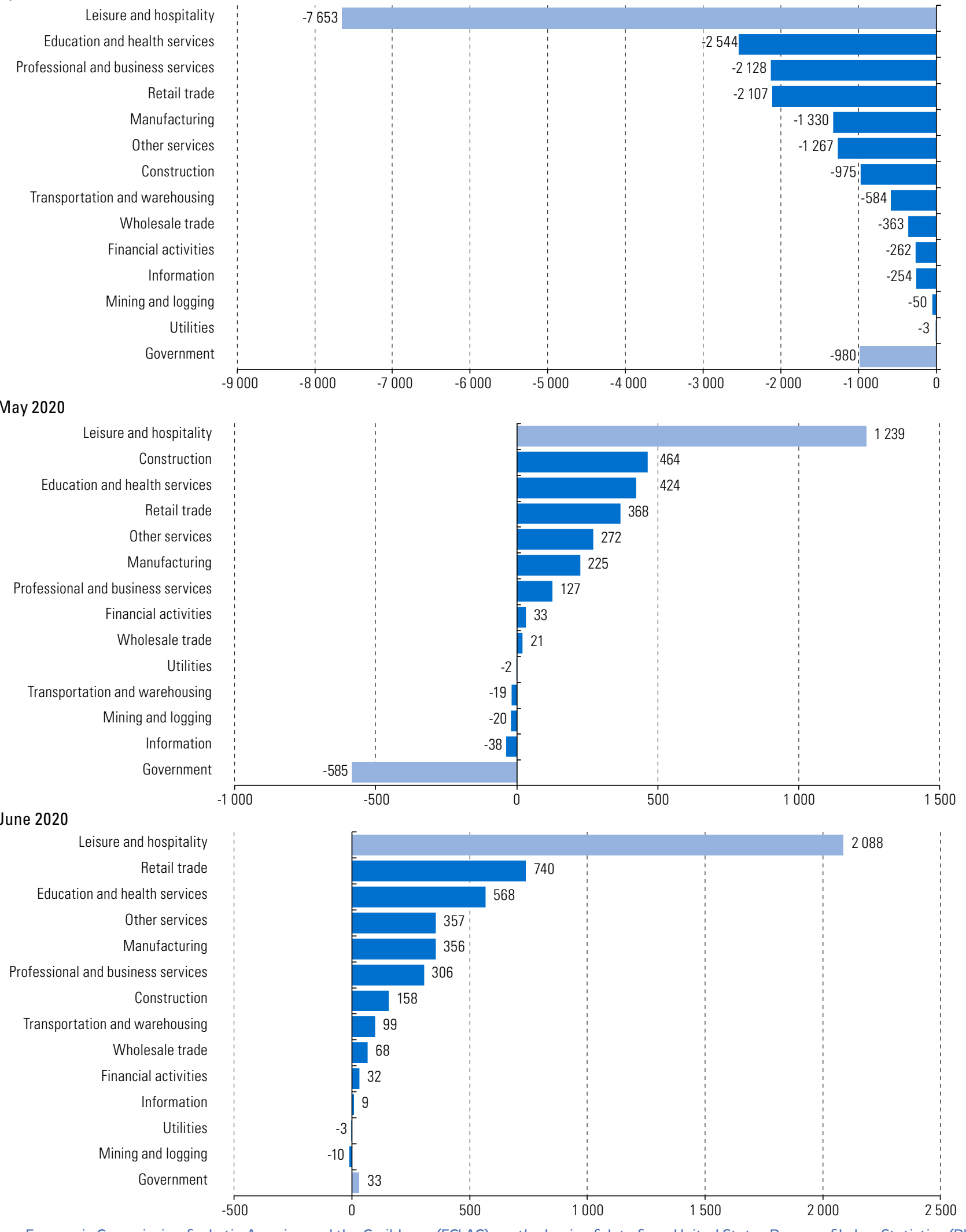

Source: Economic Commission for Latin America and the Caribbean (ECLAC), on the basis of data from United States Bureau of Labor Statistics (BLS), "Current Employment Statistics" [online] https://www.bls.gov/ces/. 


\section{Slump in industrial production and retail sales}

The pandemic combines aspects of both supply and demand shocks (Brinca, Duarte and Faria e Castro, 2020). Lockdown measures have affected the economy's capacity to produce goods and services, while consumers' reduced ability or willingness to purchase goods and services, amid lay-offs and fear of infection, has weakened demand.

Industrial production, a broad gauge of output from factories, mines and utilities, plunged by a seasonally adjusted $12.7 \%$ in April. This was the steepest monthly fall on record since a decline of $10.4 \%$ in August 1945, following an earlier contraction of 4.5\% in March (see figure 5), according to data from the Board of Governors of the Federal Reserve (2020a). After contracting for two months running, industrial production rose 1.4\% in May and 5.4\% in June. Manufacturing output, the biggest component of industrial production, picked up 3.8\% in May, as many factories resumed operations. It was up 7.2\% in June, but remained $11.1 \%$ below its pre-pandemic level.

Figure 5

The United States: month-on-month variation in industrial production, April 2015-June 2020

(Seasonally adjusted percentage change)

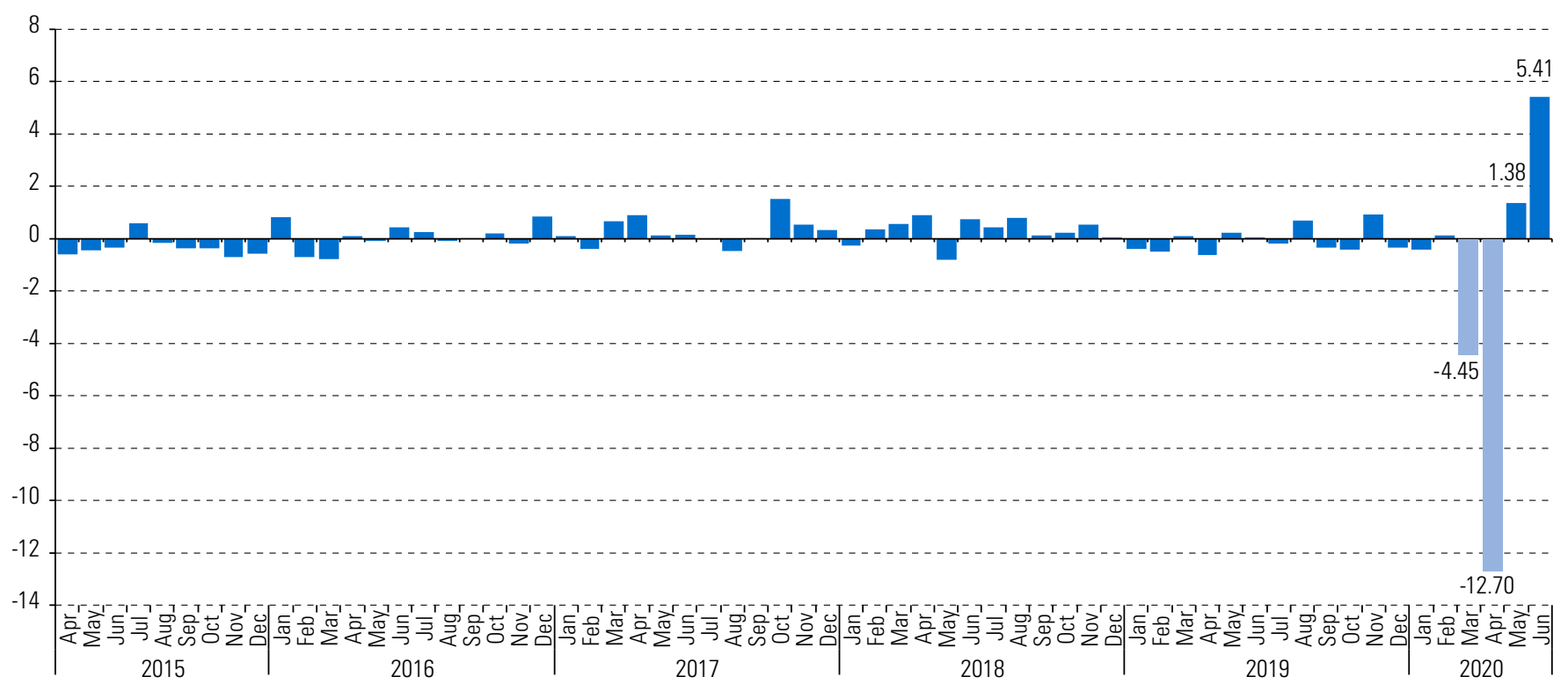

Source: Economic Commission for Latin America and the Caribbean (ECLAC), on the basis of data from the United States Federal Reserve and the Federal Reserve Bank of St. Louis (FRED)

Figures from the United States Census Bureau (2020) indicate that retail sales, a measure of purchases at stores, gasoline stations, restaurants, bars and online, fell a record $14.7 \%$ in April and 8.2\% in March, showing how the pandemic has reshaped and curbed spending habits in the United Sates. These were the largest month-on-month declines since records began in 1992. However, retail sales rebounded by an unprecedented $18.2 \%$ in May, defying expectations and more than reversing their April decline. The increase in spending came as 2.5 million employees returned to work and as household incomes were supplemented by federal support. Retail sales continued to rise in June, increasing $7.5 \%$, but that was primarily before the surge in COVID-19 infections prompted states to pause or reverse reopenings. Despite the gains, sales in June were still down 0.6\% from February.

The private sector was already highly indebted before the pandemic, making it even more vulnerable to the COVID-19 shock. In contrast to the situation during the global financial crisis of 2008-2009, the vulnerability today does not lie primarily in the financial sector, but in the broad swathe of over-indebted companies that are seeing revenues collapse 
as a result of the pandemic-induced lockdowns. The market impact of the pandemic has fuelled expectations that bankruptcy filing rates will increase. Major companies in the retail, oil and gas, leisure and hospitality, and other sectors, such as Hertz, Whiting Petroleum, Gold's Gym, Pier 1, J.Crew, JCPenney and Neiman Marcus, have already filed for bankruptcy under Chapter 11 of the United States Bankruptcy Code. This allows them to negotiate with creditors to restructure debt terms (Chapter 7 filings typically involve the liquidation of assets and permanent closure). Data from the American Bankruptcy Institute show 722 United States companies sought bankruptcy protection under Chapter 11 in May, year-on-year increase of $48 \%$. The pandemic may inflict lasting damage to the economy if business bankruptcies continue to rise and the economy's long-run potential growth rate diminishes. Policymakers will need to remain vigilant and act promptly to contain and mitigate such an eventuality.

\section{Financial markets were hit hard and fast}

The COVID-19 pandemic caused a severe and immediate shock in the global financial system. In the United States, equity markets posted in March their worst losses since the 2008-2009 financial crisis, while demand for safe haven assets, such as United States Treasury securities, increased sharply.

\section{A. Equity markets}

The bull market that began in March 2009, when the Standard \& Poor's 500 (S\&P 500) bottomed out after the global financial crisis, had lasted just over 10 years by end-2019, making it the longest in history. However, it came to an end in early 2020. On 31 March, United States stocks closed out their worst quarter since the depths of the financial crisis, with markets reeling from the staggering losses inflicted by an economy paralyzed by the coronavirus disease. Stock prices reached a peak in February and a nadir in March (see figure 6).

Figure 6

The United States: stock market indices, June 2010-June 2020

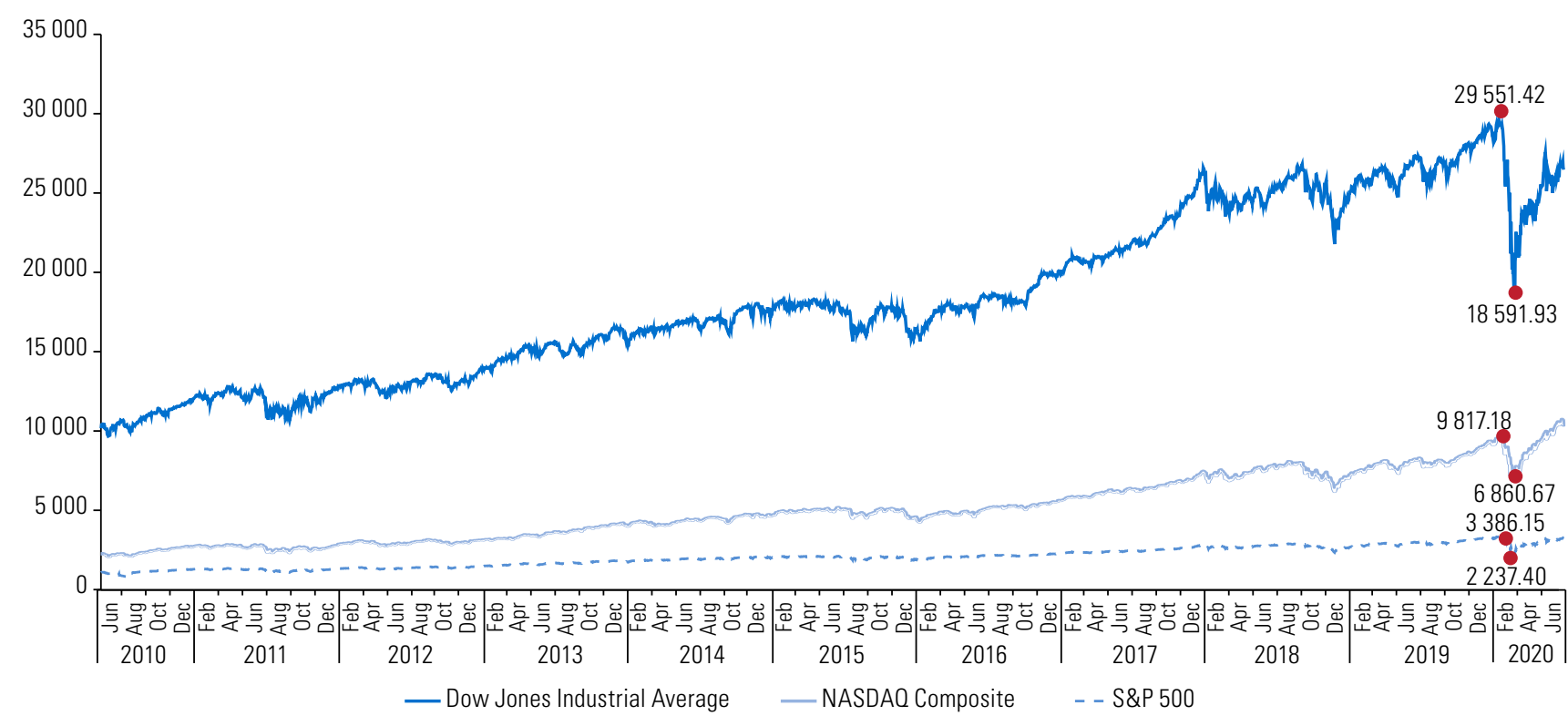

Source: Economic Commission for Latin America and the Caribbean (ECLAC), on the basis of data from the Federal Reserve Bank of St. Louis (FRED) ${ }^{a}$ Indices are not seasonally adjusted.

The S\&P 500 posted a 20\% loss for the first quarter of 2020 (based on daily closing prices), its biggest decline since 2008, while the quarterly loss of the Dow Jones Industrial Average was 23\%, its worst showing since 1987. The NASDAQ Composite finished the quarter down $14 \%$ 
However, stocks have since recovered. In the second quarter, the Dow Jones Industrial Average, the S\&P 500 and the NASDAQ indices gained 18\%, 20\% and 31\%, respectively. Following the release of May's positive job numbers in early June, Hertz, Whiting Petroleum, Pier 1 and JCPenney, which had all declared bankruptcy at the height of the pandemic, saw their shares surge in a market rally. While companies that enter Chapter 11 often survive, their stockholders usually register big losses. The recent behaviour of stock prices has raised concerns that there is a disconnection from the real economy, where volatility and uncertainty remain high.

Whether too much corporate borrowing will hinder the economy is a concern for financial markets. Non-financial corporations entered this crisis with significant debt loads, borrowing not for investment purposes, but in order to buy stocks and pay dividends to shareholders. Excessive borrowing could make it harder for the economy to recover. Another matter of concern is the impact of stock market volatility on pension funds and retirement incomes.

\section{B. Bond markets}

Demand for safe havens assets, including United States Treasury notes, has increased sharply as volatility and uncertainty spike. United States Treasury security yields plummeted in the first quarter of 2020 as a result. The decline in short-term Treasury yields was steeper than the declines in longer Treasury maturities. In the first quarter, the 3-year, 10-year and 30-year Treasury yields fell 82\%, 64\% and 44\%, respectively. At end-June, 3-year, 10-year and 30-year Treasury yields were 87\%, 59\% and 33\% lower, respectively, than in mid-February, before the pandemic hit (see figure 7). The decline in Treasury yields is a sign that economic doubts and aggressive monetary stimulus remain powerful forces holding down long-term interest rates.

Figure 7

The United States: daily yields on Treasury constant maturities, June 2015-June 2020

(Percentages)

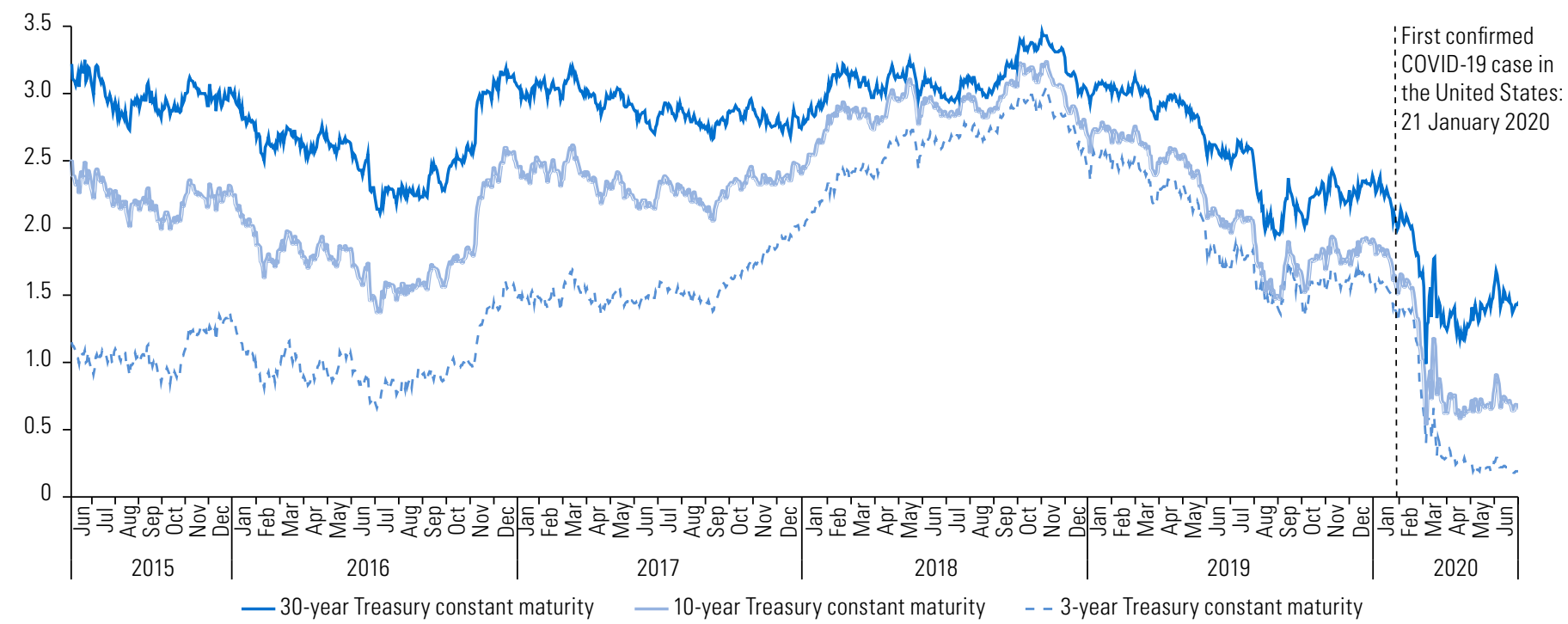

Source: Economic Commission for Latin America and the Caribbean (ECLAC), on the basis of data from the Federal Reserve Bank of St. Louis (FRED)

\section{Financial conditions in Latin America and the Caribbean}

Amid the collapse of the financial markets in the initial stages of the COVID-19 crisis, there was a massive outflow of portfolio capital from emerging economies. The International Monetary Fund (IMF) estimated this capital flight at more than US\$100 billion, exceeding that which followed the collapse of the Lehman Brothers investment bank in 2008 that triggered the global financial crisis. 
The immediate impact of the pandemic on financial conditions in Latin America and the Caribbean was deleterious, as there was a flight from risk amid a global economic slump, which was exacerbated by a sharp decline in commodity prices, remittances, tourism receipts and world trade. The financial situation was made worse by a strong United States dollar.

However, massive intervention on the part of the Federal Reserve ${ }^{5}$ and other central banks has managed to stabilize financial markets since end-March and even produced a recovery in the world's stock exchanges. This stabilization process has also led to an improvement in private lending to emerging economies.

\section{Debt issuance}

Backed by favourable market conditions (a combination of ample liquidity, low global interest rates and a risk-on sentiment) at the start of 2020, sovereign and corporate borrowers in Latin America and the Caribbean placed bonds worth a record US $\$ 38$ billion in January (surpassing the previous high registered in January 2018). Subsequently, the spread of COVID-19 radically changed the landscape, as prices of commodities - a major source of income for many countries of the region - plummeted, and the issuance of new cross-border debt dried up in February and March (see figure 8).

Figure 8

Latin America and the Caribbean: monthly debt issuance, June 2017-June 2020

(Billions of dollars)

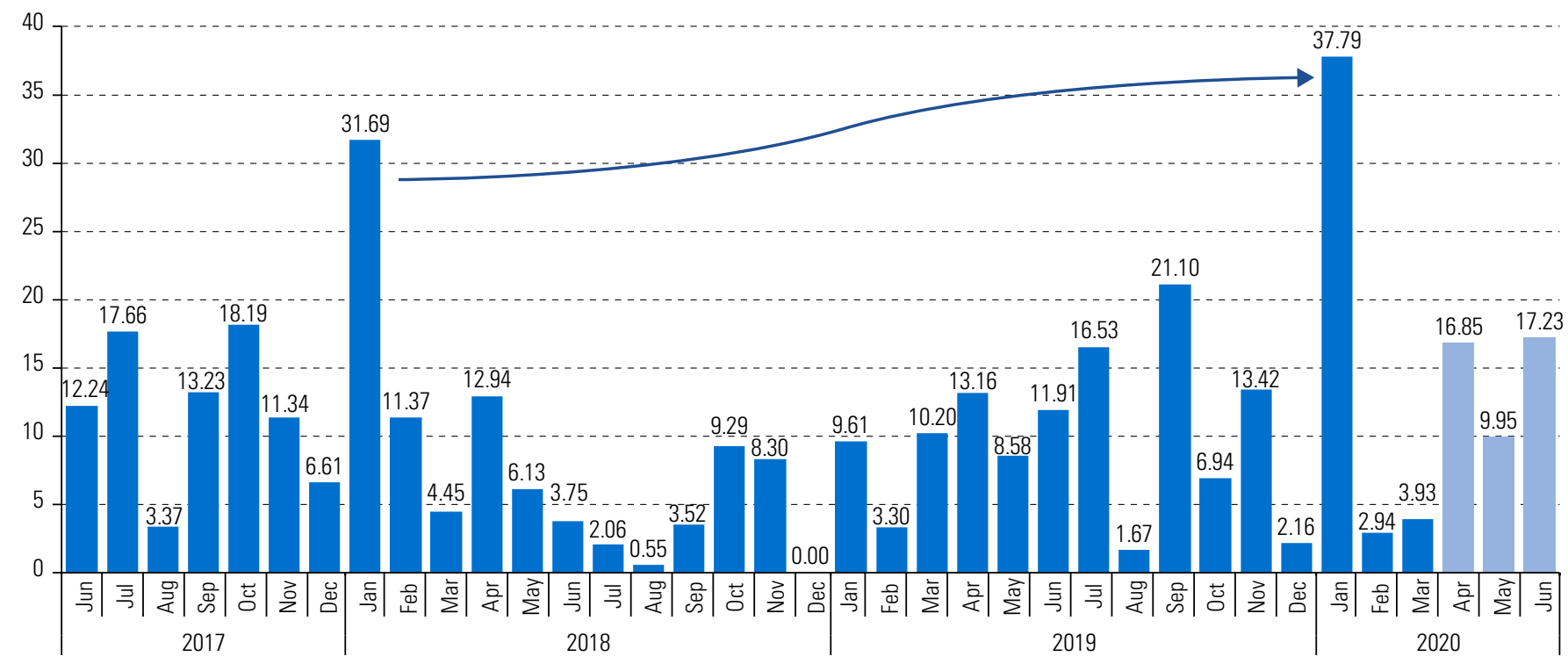

Source: Economic Commission for Latin America and the Caribbean (ECLAC), on the basis of data from Dealogic and LatinFinance.

After this two-month pause in the wake of the COVID-19 crisis, unprecedented sovereign issuances in April led to a rebound in the region, as widening financing gaps triggered by the COVID-19 pandemic and the sudden drop in oil prices pushed up the issuance volume. ${ }^{6}$ New issuances in the second quarter have more than compensated for this earlier decline. Total issuance for the second quarter of 2020 was up 31\% year-on-year.

The response of the Federal Reserve is outlined in section VII of this report.

On 26 March, Panama issued sovereign bonds in international markets to secure additional resources to tackle the COVID-19 pandemic. It was followed in April by four other countries from the region - Guatemala, Mexico, Paraguay and Peru - all tapping international debt markets with sizeable issuances to raise funds to address the pandemic. There was strong demand for the bonds. Together, these five sovereign issuances amounted to US\$ 13 billion in new cross-border bonds. 


\section{Debt spreads}

Debt spreads in Latin America and the Caribbean widened by 357 basis points in the first quarter, with the biggest gap in March (275 basis points). At the end of March, regional spreads were at 703 basis points, very close to the peak reached in November 2008 during the global financial crisis. However, debt spreads have since trended down (see figure 9).

Figure 9

Daily spreads in the Emerging Market Bond Index (EMBI) Global and Latin America, 2008-2020

(Basis points)

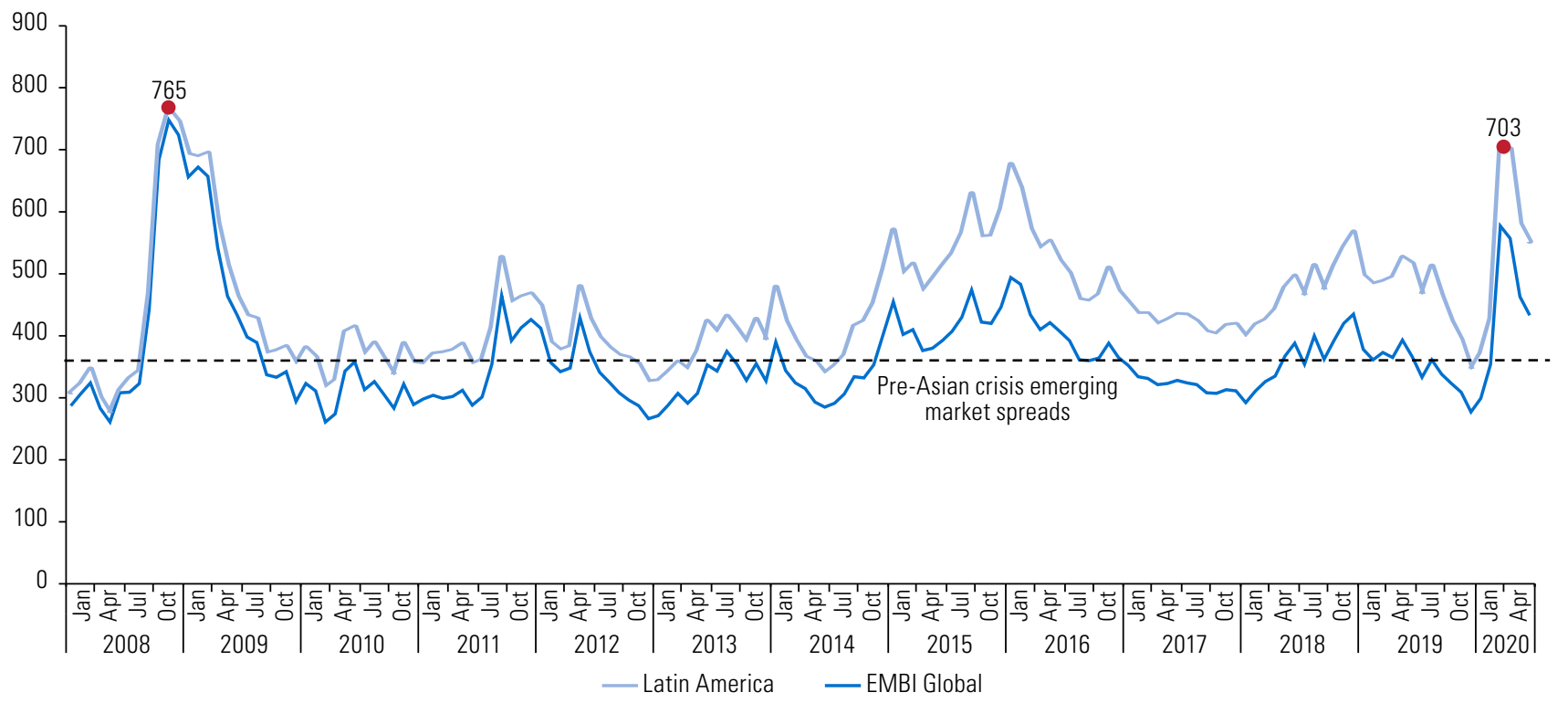

Source: Economic Commission for Latin America and the Caribbean (ECLAC), on the basis of data from JPMorgan, Emerging Markets Bond Index Monitor.

\section{Equity prices}

The pandemic also had an immediate effect on Latin American currencies and equities, with most currencies depreciating and equities being sold off. The MSCI Emerging Markets Index for Latin America was down $46 \%$ in the first quarter, while the indices for emerging markets and the Group of Seven (G7) countries fell by $24 \%$ and $21 \%$ respectively. Latin American equities were at their lowest on 23 March, when stock prices tumbled 53\% (see figure 10).

The underperformance of Latin American equities was due, in part, to currency depreciation and, in part, to the effects of the pandemic and the oil shock on the region. However, the aforementioned widening in sovereign spreads and the depreciation of Latin American and Caribbean currencies were less pronounced than during the global financial crisis.

Since bottoming out in March, stock prices have seen a partial recovery, attenuating the total losses. In the first half of the year, the MSCI Latin American index dropped 36\%, while emerging markets stocks fell by $11 \%$ and $\mathrm{G} 7$ countries by $6 \%$. 
Figure 10

Stock market price indices, 1 January-30 June 2020

(MSCI Equity Index, 1 January 2020=100)

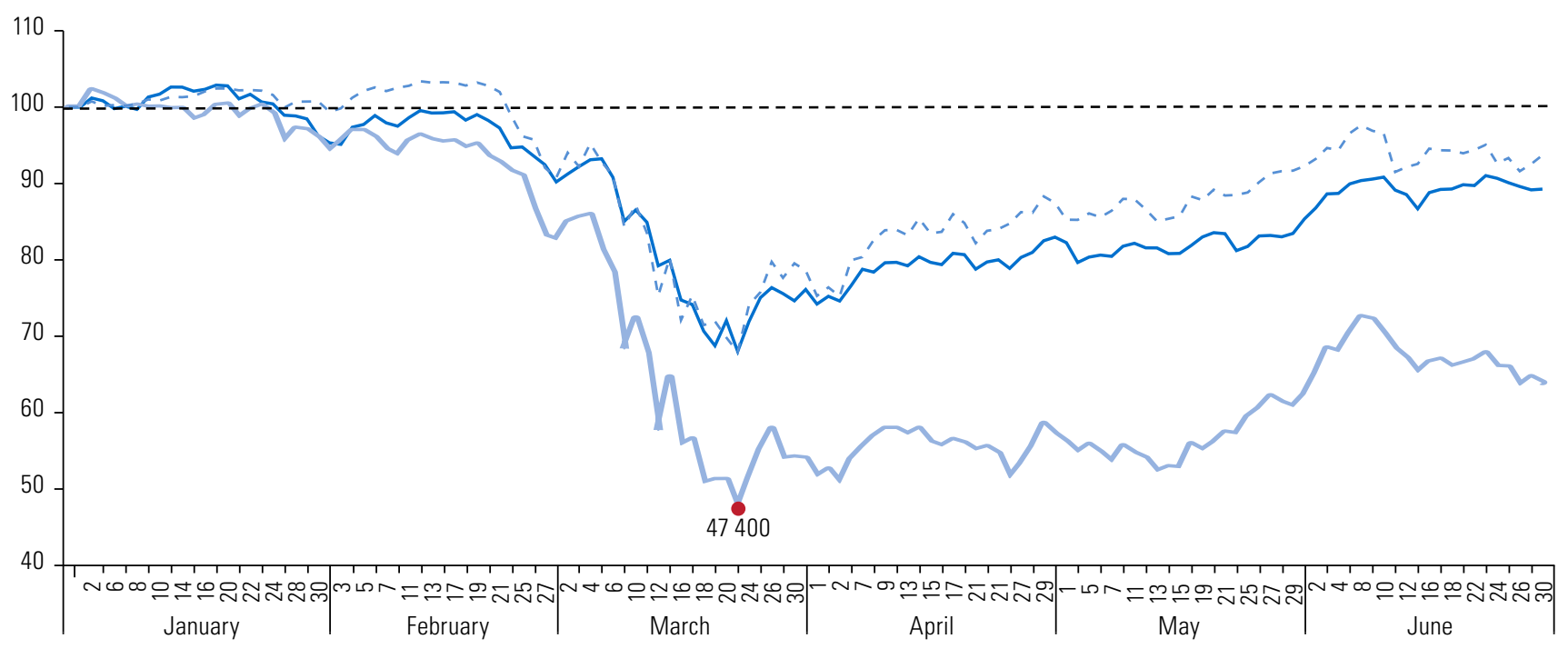

_ Latin American emerging markets _-Emerging markets _ - G7 countries

Source: Economic Commission for Latin America and the Caribbean (ECLAC), on the basis of MSCI, "Index solutions" [online] http://www.msci. com/products/indexes/performance.html.

Note: The index is based on the prices at the end of the month.

\section{Credit quality}

Credit quality in the region has deteriorated sharply since the beginning of 2020. Negative credit rating actions (including downgrades and downward outlook revisions) have outnumbered positive actions in the region for seven years running, skewing even more negatively as the year has progressed. On balance, there have been 27 more downgrades than upgrades since the beginning of the year (see figure 11). There has been an increasing number of negative outlooks as well, suggesting that further downgrades are possible.

\section{Figure 11}

Latin America and the Caribbean: net credit rating actions, based on upgrades and downgrades, first quarter of 2015-second quarter of 2020

(Number of actions)

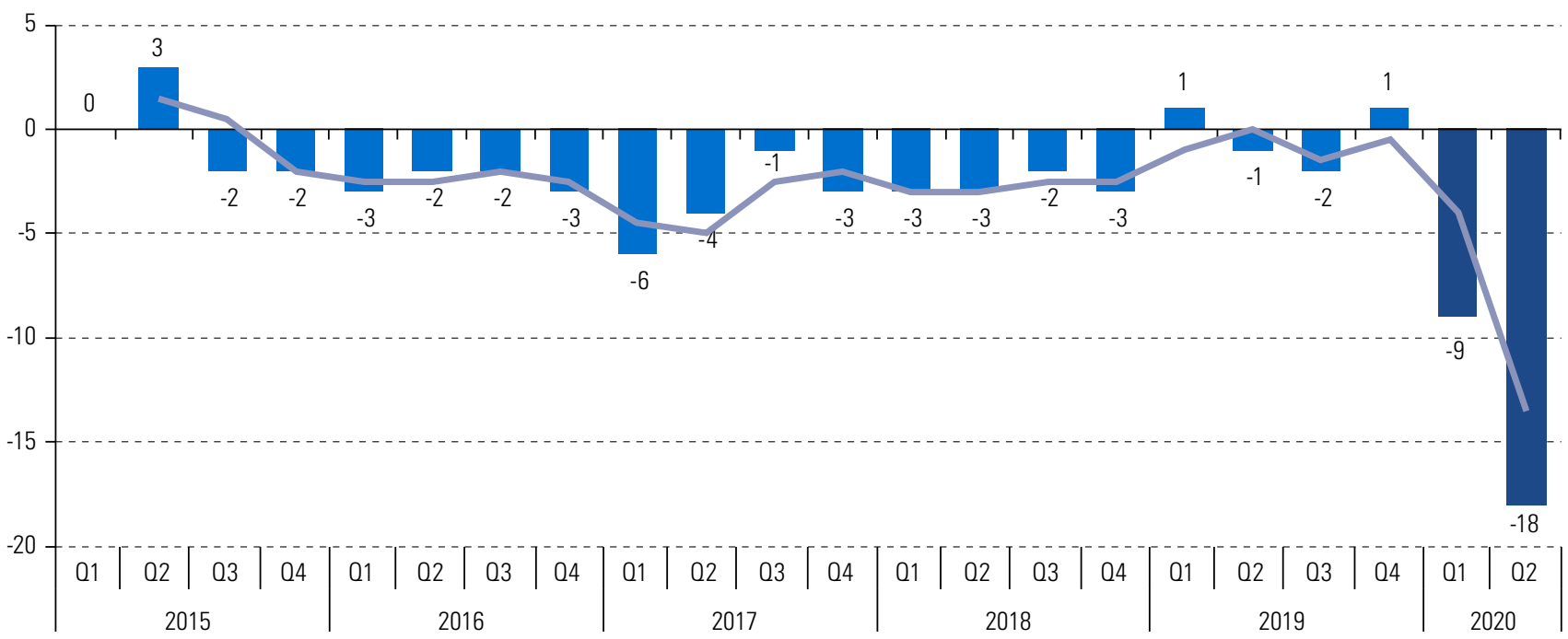

Source: Economic Commission for Latin America and the Caribbean (ECLAC), on the basis of data from Moody's, Standard \& Poor's and Fitch. 
In the month of April alone, there were 22 negative actions, 14 of them downgrades, on account of the impact of the COVID-19 outbreak. The commodity exporters of the region, particularly oil-exporting countries, were hit the hardest by the downgrades, having also been buffeted by the oil price shock, higher volatility and tighter financial conditions.

Downgrades have revived old criticisms that the credit rating agencies tend to aggravate financial conditions when there is a dire need for financing to fight the corrosive effects of a crisis. Diminished credit quality in an environment of tight financial conditions and risk aversion is a concern for issuers.

\section{Disrupted trade flows and supply chains}

The global pandemic has severely affected several industries worldwide as whole sectors of the economies have been shut down, leading to major disruptions in the supply of goods and services. Massive layoffs and loss of income have also weakened global demand significantly. Restrictions on movement and physical distancing measures have directly affected transportation, travel and tourism — all industries directly linked to trade in services. The effects on trade flows are further magnified by trade restrictions imposed on critical medical supplies and pharmaceutical products and, potentially, food products.

In the United States, exports of goods and services fell by US\$ 141.5 billion or 13.6\% and imports were down US\$ 173.1 billion or 13.3\% in the first five months of 2020 relative to the year-earlier period. As a result, the trade deficit shrank by US\$ 32 billion (12.2\%). The industries in which exports contracted the most were automotive vehicles, parts and engines (down US\$22.8 billion or 33\%); consumer goods (US\$19.2 billion or 21.9\%); capital goods (US\$ 37.0 billion or 15.9\%); travel services (US\$ 33.3 billion or 41\%, and transportation services (US\$12.8 billion or 33\%). Meanwhile, in the same period, the biggest drops in imports were also in automotive vehicles, parts and engines (which fell by US\$ 49.1 billion or 30.9\%); goods such as cell phones and other household goods (US\$ 36.3 billion or 13.2\%); capital goods (US\$ 28 billion or 9.8\%); travel services (US\$ 29.1 billion or 52.3\%); and transport services (US\$15.2 billion or 33.6\%). ${ }^{7}$ The fall in trade in services is directly related to the containment measures adopted to bring the spread of COVID-19 under control.

United States trade fell most sharply in April 2020 (see figure 12), as citizens were encouraged to stay home and other measures were implemented to slow the spread of COVID-19. The shutdown of the United States economy started in mid-March and continued until at least mid-May when some states slowly began to reopen their economies.

Figure 12

The United States: monthly trade in goods and services, 2020

(Billions of dollars)

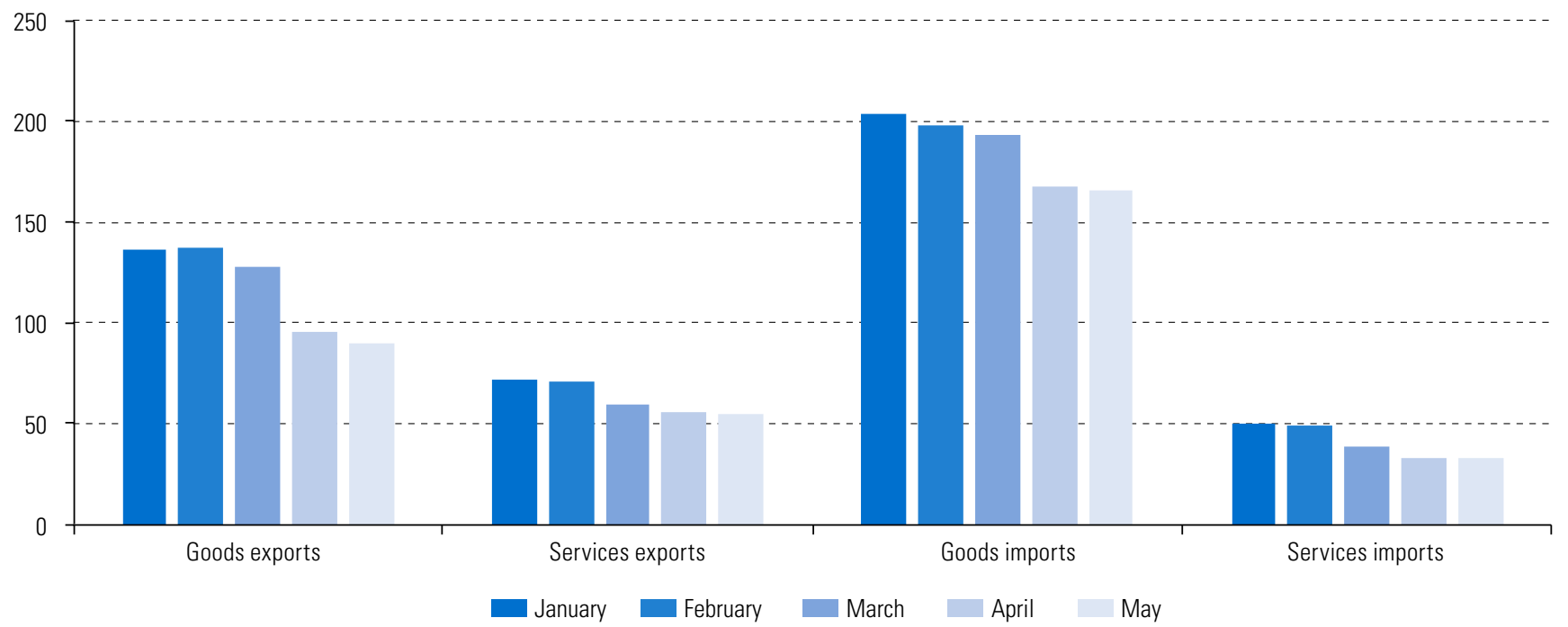

Source: Economic Commission for Latin America and the Caribbean (ECLAC), on the basis of data from the Bureau of Economic Analysis (BEA) of the United States Department of Commerce, and the United States Census Bureau.

Figures based on official data. 


\section{A. Trade with Latin America and the Caribbean}

The decline in economic activity in the United States has a direct impact on the region. One of the primary channels of transmission is through trade flows. In the first five months of the year, total United States trade with Latin America and the Caribbean contracted by 26\%, down from US\$ 369.4 billion in 2019 to US\$292.8 billion in 2020. Exports of goods and services shrank by US\$ 35.8 billion while imports fell US\$ 40 billion. This resulted in an improvement in the trade balance with the region.

South America was the subregion where trade with the United States saw the largest percentage drop, falling $20.4 \%$. This is explained primarily by the fact that trade with the Bolivarian Republic of Venezuela plunged $82 \%$, while trade with Paraguay and Argentina fell by $46 \%$ and $31 \%$, respectively. United States trade with the Caribbean contracted by $14.5 \%$ in the first five months of 2020, while trade with Central America and Mexico declined by $12.5 \%$ and $22 \%$, respectively.

United States exports of automotive vehicles and parts in April were roughly one third of the March value, falling from US\$12.600 billion in March to US\$ 4.064 billion in April. Imports more than halved, shrinking from US\$ 30.067 billion to US\$13.517 billion in April. Among the trading partners most affected in this industry were Canada and Mexico because the automotive industry is highly integrated through the North American value chain.

The nature of the containment measures - border closures, travel bans and quarantine measures - poses unprecedented challenges to the tourism industry. Many of the countries that have been most severely affected by the health crisis also play a crucial role in the tourism industry, both as destinations for and sources of tourists. According to the World Tourism Organization (UNWTO), they account for between $55 \%$ and $88 \%$ of global tourism expenditures. The tourism industry is vital to several countries in the Caribbean. The current context is therefore especially challenging for countries such as Antigua and Barbuda, the Bahamas, Belize, Saint Kitts and Nevis, Saint Lucia and Saint Vincent and the Grenadines, where inbound tourism represents more than a quarter of total GDP (UNWTO, 2020)

\section{B. Supply value chains}

The COVID-19 pandemic has also exposed the United States' dependency on critical medical equipment, personal protective equipment (PPE), and pharmaceuticals from abroad, as well as the need to coordinate health emergency measures with its immediate neighbours to avoid disruption to their very integrated economies. It has also highlighted the need for food supply chains to be made more resilient in order to ensure food safety in the United States. As a result, the United States Trade Representative (USTR) has called for a post-pandemic industrial policy that could include increased tariffs and subsidies to reshore certain supply chains (The Economic Club of New York, 2020).

Supply chains have been disrupted across the economy. The medical, automotive and food supply chains exhibited severe disruptions, as illustrated below.

\section{The medical supply value chain}

The health crisis that started in China at the beginning of 2020 reduced exports from that country and, among other effects, led to shortages of critical medical supplies worldwide and in the United States, in particular. China is a major global supplier of PPE, medical devices, antibiotics and active pharmaceutical ingredients (Sutter, Sutherland and Schwarzenberg, 2020).

Shortages have been exacerbated by the spike in global demand for these products as the COVID-19 pandemic spread worldwide and several countries placed restrictions on exports of critical medical products. In the United States, analysts and industry groups have also pointed to the role of tariffs in diminishing United States imports of health and medical products from China, contributing to the shortage of medical equipment. Tariffs on these products had been raised starting in September 2019 in the context of trade tensions between the United States and China.

The United States trade response to the COVID-19 crisis has revolved around reducing its dependence on foreign production of medical supplies through the diversification of supply 
chains and taking measures to promote domestic production of critical medical supplies and equipment. The United States also joined a host of other countries in restricting exports of medical supplies as of 10 April 2020.

(a) On 17 March, the USTR approved the exclusion of surgical masks and disposable respirators from the list of products imported from China subject to ad valorem duties in the context of the United States-China trade dispute. United States tariffs had been penalizing imports of surgical masks and disposable respirators from one of the world's largest suppliers.

(b) President Trump formally invoked the Defense Production Act (DPA) to fill the gaps in medical supplies to fight the COVID-19 pandemic. On 2 April, the United States Administration invoked the DPA to require the company, 3M, to prioritize orders from the Federal Emergency Management Agency (FEMA) for N95 respirators. Concurrently, President Trump asked that $3 \mathrm{M}$ increase the number of respirators imported from its overseas operations, including from China, into the United States. The Administration also requested that $3 \mathrm{M}$ cease exporting respirators currently manufactured in the United States to Canada and Latin American countries -in 2019, 34\% of 3M United States production of $\mathrm{N} 95$ respirators was exported to Canada and 30\% to Mexico. This last request was later withdrawn. Several of the largest car companies, including General Motors, Ford, Fiat Chrysler Automobiles and Tesla, have also switched to the production of masks, ventilators, and face shields instead of cars.

(c) On 7 April, FEMA issued a temporary final rule published in the Federal Register Notice of 10 April 2020 (see section 328.102(a) of the new Title 44 Code of Federal Regulations), "Prioritization and Allocation of Certain Scarce or Threatened Health and Medical Resources for Domestic Use". The temporary final rule established that some medical equipment needed to combat COVID-19 cannot be exported from the United States without the explicit approval of FEMA. Designated materials under this rule include filtering facepiece respirators (for example, those designated as N95, N99, N100, R95, R99, R100, or P95, P99, P100); elastomeric, air-purifying respirators and appropriate particulate filters and cartridges; PPE surgical masks; and PPE gloves or surgical gloves. This new United States export restriction means FEMA can limit what companies such as $3 \mathrm{M}$ can sell to hospitals in Canada and Mexico

(d) On 14 April, the Export-Import Bank of the United States (EXIM) announced new temporary restrictions - until 30 September 2020 - on financing United States exports of scarce medical supplies, including respirators, masks, gloves, Tyvek suits, face shields and similar protective wear needed to fight the COVID-19 pandemic. According to EXIM authorities, financing for medical equipment exports accounts for a small share -less than $1 \%$ - of the overall financing portfolio.

(e) The Coronavirus Aid, Relief, and Economic Security (CARES) Act (Public Law No. 116-136), includes several provisions that seek to enhance the understanding of United States medical supply chain dependencies (Sutter, Sutherland and Schwarzenberg, 2020), including to:

(i) Expand drug shortage reporting requirements;

(ii) Require certain drug manufacturers to draw up risk management plans;

(iii) Require the United States Food and Drug Administration (FDA) to maintain a public list of medical devices for which there is determined to be a shortage; and

(iv) Direct the National Academies of Science, Engineering, and Medicine to conduct a study of pharmaceutical supply chain security.

Many countries in Latin America are dependent on United States exports of medical supplies for at least one of the products listed in the export restrictions under the new temporary final rule (Bown, 2020; ECLAC, 2020).

At the same time, the United States depends on global (and hemispheric) supply chains. In many cases, the production facilities of high quality, safe PPE are in Central America, the Caribbean and Mexico. As the United States looks at health care through a national security lens and re-evaluates the benefits and costs of diversifying sources of supply, new opportunities could arise for countries in Latin America and the Caribbean to export to the United States market. 


\section{The North American automotive industry}

The global and North American automotive supply chain has been severely affected by the pandemic. China is a major supplier of parts to automobile plants around the world - shipping parts worth US\$ 34.8 billion in 2018 (United Nations, 2020; Richter, 2020). About US\$ 11.7 billion of Chinese-made parts were exported to the United States that year, according to the United States International Trade Administration (ITA) (United Nations, 2020; Richter, 2020). While some go to automotive parts retail stores, a large percentage go to assembly lines and are used to build cars. Hence, they are a crucial link in the North American supply chain. It is estimated that the spread of the coronavirus will negatively impact between $16 \%$ and $45 \%$ of the production of North American automobile companies.

The Mexican Association of Automobile Distributors (AMDA) expects sales of all new vehicles made in the country to drop by at least $26 \%$ in 2020, to about 982,000 cars and light trucks - or more than 330,000 units less than the previous year- similar to the figures seen during the 2008-2009 financial crisis (Automotive News, 2020). The Mexican Automotive Industry Association (AMIA) estimates that the industry accounts for about $3.8 \%$ of the country's GDP and generates about 980,000 direct jobs (Reuters, 2020).

Since the precursor of the United States-Mexico-Canada Agreement (USMCA), the North American Free Trade Agreement (NAFTA) entered into force 26 years ago, automotive production has been strongly linked among the three countries through supply chains. When COVID-19 struck, measures taken at different points in time by the governments of the three countries to contain the spread of the pandemic and protect the health of workers halted production in several activities, including operations in the automotive sector. The closely interconnected supply chains were disrupted, highlighting the need to coordinate health emergency measures among the three governments.

At the same time, lawmakers from the Democratic and Republican parties sent a letter to the USTR, requesting that the automotive sector be given extra time to adjust to the new rules of origin for the sector enshrined in the USMCA, which entered into force on 1 July 2020. They argue that the automotive sector needs more time, in part because the COVID-19 has caused the temporary closure of some production facilities, while others have switched operations from the production of cars to the production of medical equipment.

Regional content rules in the USMCA will require $75 \%$ North American content for light vehicles compared to $62.5 \%$ under NAFTA, and $40 \%$ content for cars produced in areas that meet a certain wage threshold ("high wage" areas). This is to be phased in over three to four years, but automakers were required to certify compliance with the initial requirements when the agreement entered into force.

The United States automotive industry hoped some changes could be made to the uniform regulations, agreed on 3 June among the three countries party to the agreement, before the trade deal took effect. The uniform regulations outline the rules of origin for the USMCA, including the complex rules for automobiles. The regulations provide details on the calculations to be used for regional content value and the records that must be kept by automakers to prove compliance. The regulations provide a six-month transition period from the 1 July implementation date to the end of 2020.

Table 1 includes information on several actions taken by the leading carmakers in the United States. On 8 April 2020, the United States Department of Health and Human Services issued the first contract to General Motors, worth US\$ 489 million, to build 30,000 ventilators under the Defense Production Act. 
Table 1

Selected actions taken by the automotive industry

\begin{tabular}{|c|c|c|c|c|c|c|}
\hline & Status & $\begin{array}{l}\text { Date of } \\
\text { closure }\end{array}$ & $\begin{array}{l}\text { Date of } \\
\text { reopening }\end{array}$ & $\begin{array}{l}\text { Reopened to other } \\
\text { manufacturing }\end{array}$ & $\begin{array}{l}\text { Furloughed } \\
\text { employees }\end{array}$ & $\begin{array}{l}\text { Number of } \\
\text { employees }\end{array}$ \\
\hline General Motors & Open & 19 March & 18 May & Ventilators and PPE & 50000 & 86400 \\
\hline Ford Motor Company & Open & 19 March & 18 May & Ventilators and PPE & 50000 & 85000 \\
\hline Toyota Motor Corporation & Open & 23 March & 11 May & & 5000 & 136000 \\
\hline Fiat Chrysler Automobiles & Open & 18 March & 18 May & Face mask production & 50000 & 77000 \\
\hline Honda Motor Company & Open & 18 March & 11 May & & 14000 & 27000 \\
\hline Nissan Motor Company & Closed & 20 March & Indefinite & & 10000 & 22000 \\
\hline Hyundai Kia Automotive Group & Open & 30 March & 5 May & & & 31000 \\
\hline Subaru Corporation & Open & 29 March & 18 May & & & 5300 \\
\hline Volkswagen Group & Open & 17 March & 18 May & & & 8000 \\
\hline Mazda & Open & 24 March & 1 June & & & 20000 \\
\hline Tesla & Open & 23 March & 18 May & Face mask production & & 48000 \\
\hline BMW Group & Open & 29 March & 4 May & & 11000 & 11000 \\
\hline Volvo & Open & 26 March & 11 May & & & 17000 \\
\hline
\end{tabular}

Source: Economic Commission for Latin America and the Caribbean (ECLAC), on the basis of newspaper articles, industry-specific publications and periodical trade publications.

\section{The food supply chain}

Food supply chains have also been severely affected by the pandemic. As restaurants, hotels and schools closed, United States farmers found it difficult to redirect their produce to willing buyers and even then, they were unable to sell most of it owing to logistics difficulties. Retailers saw a spike in demand for food products as most meals were now being prepared at home, but that was not enough to absorb the perishable products meant for schools, restaurants and other businesses. Even food banks and Meals on Wheels programs, which have been overwhelmed with demand, do not have the number of refrigerators or volunteers needed to absorb the surplus.

Moreover, many meat processing plants were forced to close temporarily after several workers tested positive for COVID-19. This increased pressure on the supply of food, particularly meat, to the domestic market. The food processing industry is very vulnerable to COVID-19 outbreaks as employees work in close proximity to one another. This is compounded by the lack of sufficient testing, which results in potentially infected workers remaining untested and therefore precipitating the spread of the disease.

The major meat processors that have had to shut down plants include: Smithfield Foods, which processes about $5 \%$ of the pork produced in the United States; JBS USA, the North American arm of JBS S.A., the world's largest meat processor; Cargill, specifically the facility in Pennsylvania which produces steaks, ground beef and ground pork; and Tyson Foods, specifically the company's pork processing plant in Iowa.

In this context, the United States Department of Agriculture (USDA, 2020) announced the Coronavirus Food Assistance Program (CFAP), which includes two major elements

(a) Direct support to farmers and ranchers: The program will provide US\$ 16 billion in direct support, based on actual losses for agricultural producers where prices and market supply chains have been impacted, and will assist producers with additional adjustment and marketing costs in 2020 resulting from lost demand and short-term oversupply caused by COVID-19.

(b) USDA purchase and distribution: USDA will partner with regional and local distributors, whose workforce has been significantly impacted by the closure of many restaurants, hotels and other food service entities, to purchase US\$ 3 billion in fresh produce, dairy products and meat. The distributors and wholesalers will then provide a pre-approved box of fresh produce, dairy and meat products to food banks, community and faithbased organizations, and other non-profits serving Americans in need. 
In addition to these targeted programs, USDA announced it would utilize other available funding sources to purchase and distribute food to those in need

The Administration also issued an executive order to increase the country's competitiveness in the seafood industry and protect its seafood supply chain. This order instructs agencies to expand sustainable seafood production in the United States, including enabling more efficient and predictable aquaculture permitting processes, accelerating regulatory reform to maximize commercial fishing, and upholding restrictions on seafood imports that do not meet United States standards. President Trump also announced the availability of US\$ 300 million to support fishermen and related businesses hurt by the pandemic.

\section{Strong impact on migration}

\section{A. Migrant flows}

Nearly every country in the western hemisphere either closed its borders to migrants or implemented travel bans in an attempt to control the spread of COVID-19.

Measures taken in the United States included travel restrictions and specifically the suspension of entry as immigrants or non-immigrants of foreign nationals who, in the 14-day period prior, were physically in Austria, Belgium, Brazil, China, Czechia, Denmark, Estonia, Finland, France, Germany, Greece, the Holy See, Hungary, Iceland, Ireland, the Islamic Republic of Iran, Italy, Latvia, Liechtenstein, Lithuania, Luxembourg, Malta, Monaco, the Netherlands, Norway, Poland, Portugal, Slovakia, Slovenia, Spain, Sweden, Switzerland, San Marino and the United Kingdom.

The United States reached mutual agreements with Canada and Mexico to restrict non-essential travel across its northern and southern land borders. ${ }^{8}$ The United States also announced that foreign nationals who travel through ports of entry or are otherwise not allowed to enter the country will be returned immediately, as the facilities in which they would normally be held cannot support quarantine for the time needed to assess potential cases.

President Trump has ordered a series of unprecedented immigration and border restrictions. In March, he authorized United States Customs and Border Protection (CBP) to use the emergency public health authority of his Administration, under a 1940s provision of United States law, Title 42, to bypass normal immigration proceedings and expel migrants immediately. In April, the Administration announced a set of policies tightening green card eligibility. The United States Department of Education issued an emergency rule on 11 June barring colleges from granting coronavirus relief funds to foreign and undocumented students, including those protected under the Deferred Action for Childhood Arrivals (DACA) policy. The Administration has also stated that it is examining restrictions on new $\mathrm{H}-1 \mathrm{~B}$ visas for skilled workers.

As a result, unauthorized border crossings along the southern border of the United States fell 50\% in April 2020, according to figures released by federal enforcement authorities. Border authorities detained 16,039 migrants in April, down from 30,236 in March. In May, 23,197 people were apprehended at the southern border, with the upward trend continuing in June and July, when 32,935 and 40,746 people were apprehended, respectively.

In April, CBP conducted 14,416 expulsions, with United States agents detaining, processing and returning migrants to Mexico in less than a day. Consequently, the number of detainees held in United States border stations dropped from more than 3,000 per day to about 100, according to CBP.

The Mexican authorities have agreed to accept foreign nationals from El Salvador, Guatemala and Honduras expelled by the United States authorities, as well as their own citizens, and the four countries account for approximately 95\% of all illegal crossings, according to CBP (2019) figures. 


\section{B. Migrant populations in the United States}

The businesses most affected by the lockdown, such as restaurants, beauty salons, hotels and cleaning services, rely heavily on migrant workers, who are expected to be disproportionately affected by the pandemic. Many of them lack or have limited access to all forms of social protection, increasing their vulnerability.

A recent study by Borjas and Cassidy (2020) shows that immigrants were hit disproportionately hard by the effects of COVID-19 on the United States labour market. Using data from the Current Population Survey (CPS) basic monthly files, the paper shows that although historically, immigrant men were more likely to be employed than native men, by April 2020, immigrant men had lower employment rates than native men. The authors point out that the observed reversal occurred both because "the rate of job loss for at-work immigrant men rose relative to that of natives, and because the rate at which out-of-work immigrants could find jobs fell relative to the native job-finding rate". This is partly explained by the fact that immigrants were less likely to work in jobs that could be performed remotely and suffered disparate employment consequences (Borjas and Cassidy, 2020).

The Latino population in the United States has been disproportionately affected by COVID-19, accounting for a greater share of infections than would be expected based on share of the population. Lack of access to health care presents a particular challenge.

Migrants workers also contribute significantly to the agrifood industry. According to the Food and Agriculture Organization of the United Nations (FAO, 2020), migrant workers in the United States, hired to fill temporary or seasonal agriculture jobs, make up 10\% of crop farmworkers, while the seafood industry, particularly in Alaska, brings in more than 20,000 migrant workers annually. The shortage of foreign labour, owing to the closure of international borders and enforced travel restrictions, poses a tremendous challenge, with impacts on agricultural value chains, prices and availability of some products.

The United States Department of Homeland Security published the Advisory Memorandum on Identification of Essential Critical Infrastructure Workers During COVID-19 Response, which lists workers in the food supply industry, together with those in the pharmaceutical industry and those providing health-care services, as critical, and therefore with the responsibility to continue working during the health emergency. Even though they were declared, a large share of migrants work in the agricultural sector under informal or casual arrangements and are undocumented. Soon after, United States Immigration and Customs Enforcement (ICE) issued a statement announcing that, in light of the COVID-19 pandemic, it would temporarily adjust its enforcement procedures to shift focus from ordinary undocumented immigrants to those who pose a public safety or criminal threat.

However, the 60 million Hispanics currently living in the United States represent a wide range of backgrounds and lifestyles — new immigrants and multigenerational families, high-earning professionals and poor migrant farmworkers - and the effects of the pandemic reflect that broad experience.

In some states with a long-standing and more stable Hispanic population, including Arizona and Texas, state data show rates of infection similar to their share of the population. In New Mexico, Hispanics, who make up half the population and have a long history in the state, reflect roughly the same number of cases relative to the rest of the population.

The pandemic is expected to weigh on remittances. Services, especially those most reliant on migrant workers (notably hotels, restaurants, cleaning services and beauty salons), have been the most affected by restrictions on movement, physical distancing and temporary shutdowns. The jobs lost in this sector will have a direct impact on remittances. In addition, migrants who manage to keep their incomes may find it difficult to send remittances to their home countries as international money transfers are not recognized as an essential service in most countries, and banks and other agencies may be closed or operating on a reduced schedule.

The World Bank has estimated that overall remittance flows to Latin America and the Caribbean will fall by 19.3\% in 2020 (World Bank, 2020). The Inter-American Dialogue (2020) has estimated a $7 \%$ decline in remittances from the United States to Latin America and the Caribbean, from US\$ 76 billion in 2019 to US\$ 70 billion in 2020 (without calculating the damage to those directly affected by COVID-19). 


\section{United States economic policy response: strong and prompt}

The speed with which economic measures have been taken by United States policymakers to mitigate the economic impact of the pandemic on households and businesses, and the magnitude of those measures, are unprecedented.

\section{A. Monetary policy}

To address the economic disruption brought about by the COVID-19 pandemic, the Federal Reserve has taken swifter and more far-reaching actions than ever before (see figure 13). Building on its response to the global financial crisis of 2008-2009, the central bank has been able to relaunch a tested crisis toolkit, and on that basis, has also created new tools in less than 100 days since the pandemic began (compared with over 500 days in the case of the global financial crisis)

Figure 13

United States federal funds rate: then and now

(Percentages)

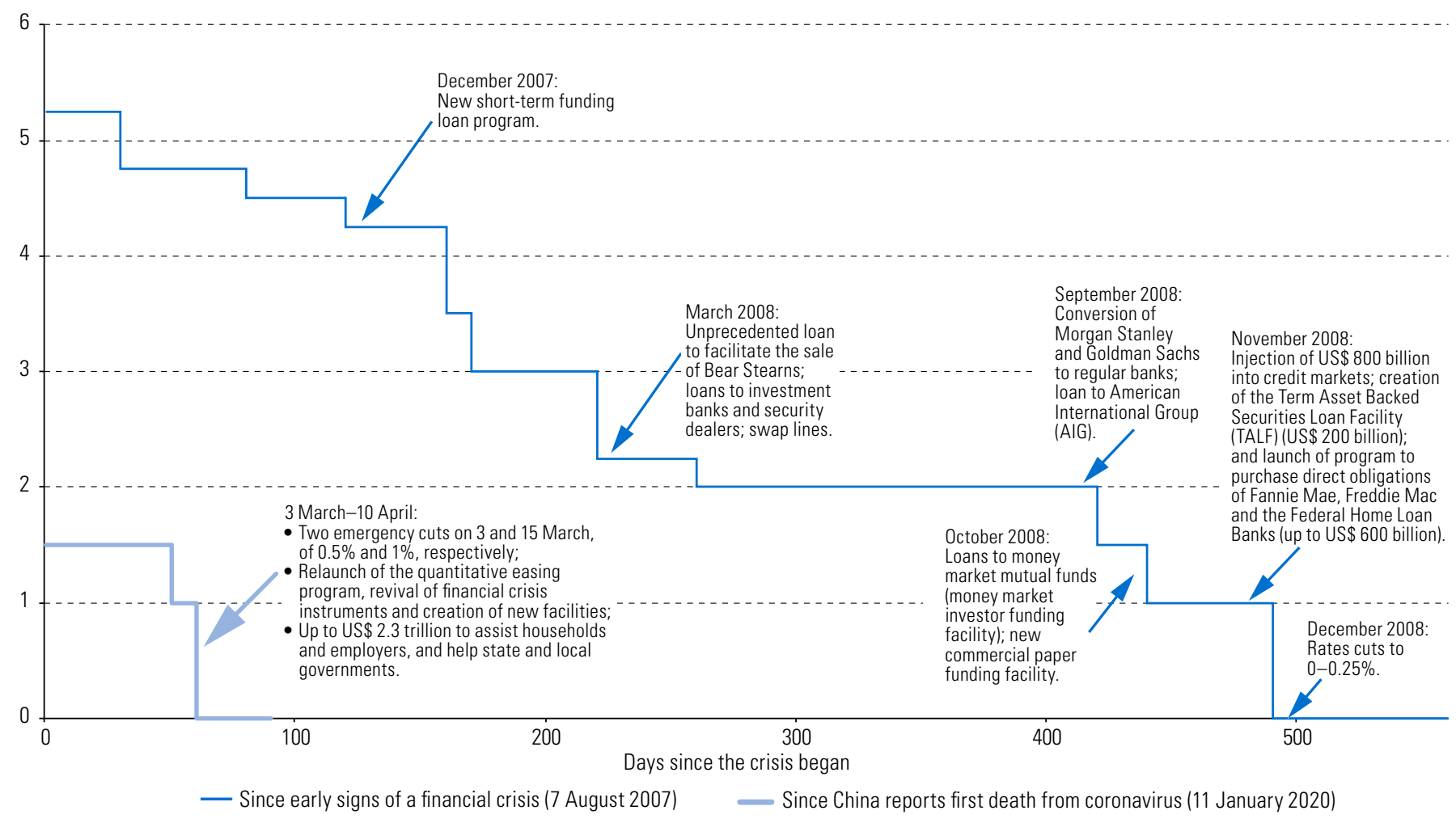

Source: Economic Commission for Latin America and the Caribbean (ECLAC), on the basis of data from the United States Federal Reserve and J. M. Schlesinger and H. Sender, "How fast the economy crashed and Washington responded -in charts", Wall Street Journal, 27 March 2020 [online] https://www.wsj.com/articles/how-fast-the-economy-crashed-and-washington-respondedin-charts-11585334137.

Note: The first signs of the financial crisis emerged in August 2007, when securities backed by subprime mortgages plummeted.

The Federal Reserve has cut interest rates, offered unlimited quantitative easing, and deployed old tools (used in response to the 2008-2009 financial crisis) and new tools aimed at keeping financial markets functioning.

\section{Interest rates}

The Federal Reserve's Federal Open Market Committee (FOMC), which sets national monetary policy, held two unscheduled meetings on 3 March and 15 March resulting in emergency interest rate cuts of $0.5 \%$ and $1 \%$, respectively. The Federal Reserve has thus 
Figure 14

United States federal funds rate

(Percentages)

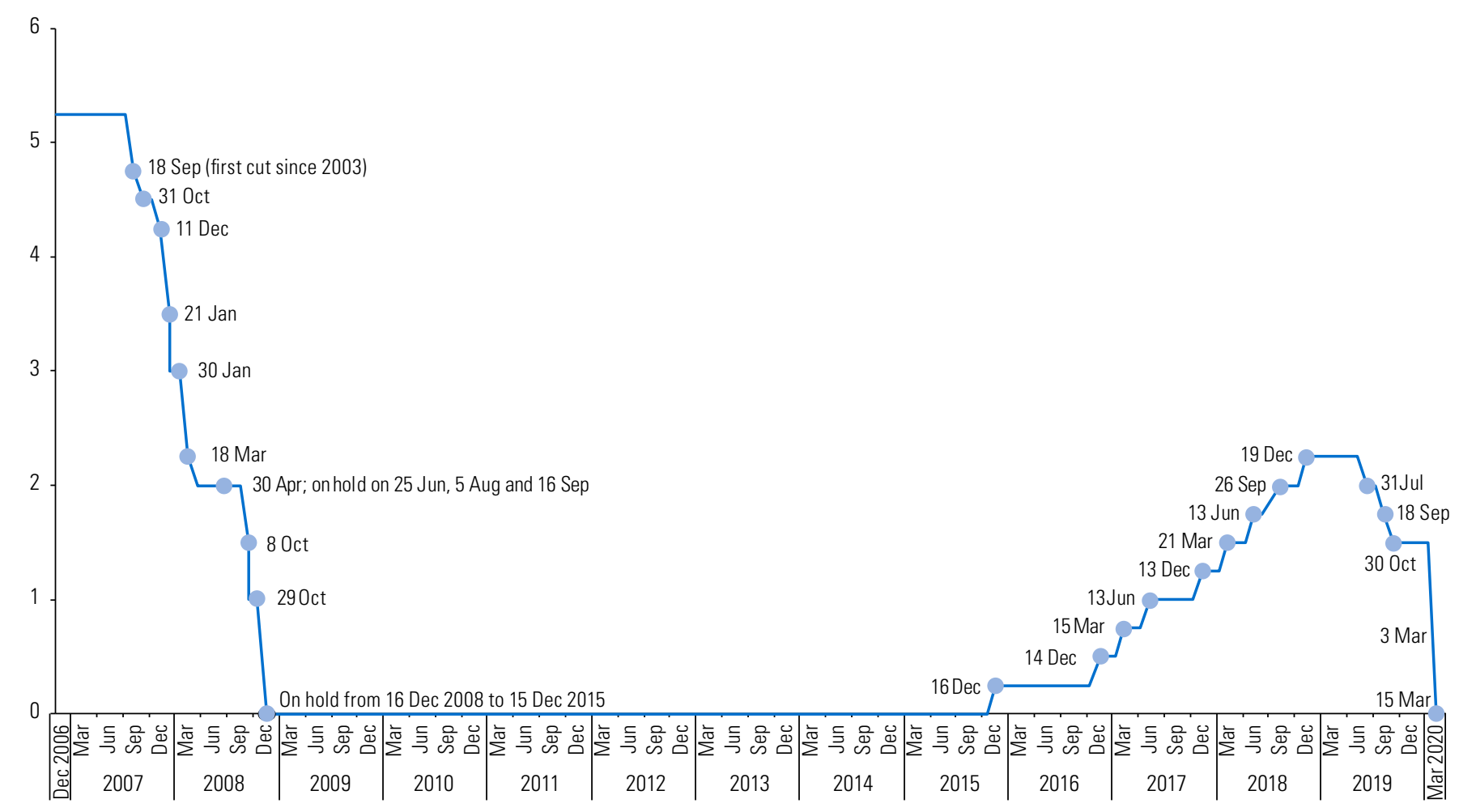

Source: Economic Commission for Latin America and the Caribbean (ECLAC), on the basis of data from the United States Federal Reserve.

\section{Quantitative easing}

The Federal Reserve restarted its quantitative easing program on 15 March, announcing it would increase its holdings of Treasury securities by at least US\$ 500 billion, and its holdings of agency mortgage-backed securities by at least US $\$ 200$ billion over the coming months to support the smooth functioning of markets for Treasury securities and agency mortgage-backed securities, which are central to the flow of credit to households and businesses. On 23 March, the Federal Reserve went further and committed to unlimited purchases of United States Treasuries and agency mortgage-backed securities. The removal of caps on planned quantitative easing purchases also meant that the Federal Reserve's balance sheet would increase markedly in size, as it became the buyer of last resort across fixed-income markets.

The Federal Reserve's balance sheet grew to a peak of US\$ 7.17 trillion by the beginning of June (the previous peak was US\$ 4.5 trillion, reached in early 2015), as US\$ 3 trillion was added in March, April and May. The increase came mainly from purchases of Treasuries and agency mortgage-backed securities (US\$ 6 trillion), but the other key component was the expansion of cross-currency swap lines (see box 1 ) by US\$ 445 billion, according to data from the central bank. So far, the demand for the Federal Reserve's supply of dollars has not outpaced that seen during the global financial crisis, which is the last time the central bank rolled out similar liquidity-boosting measures. In December 2008, at the height of the financial crisis, US\$ 583 billion were taken up through the swap lines. 
Box 1

The Federal Reserve response to the COVID-19 pandemic

Interest rates: On 15 March, the Federal Reserve brought interest rates to the zero lower bound and used forward guidance.

Quantitative easing: announced on 15 March and expanded to unlimited purchases of United States Treasuries and agency mortgage-backed securities on 23 March.

Discount window: On 15 March, the Federal Reserve opened its discount window to commercial banks, and urged them to dip into their own capital buffers to extend lending to households and businesses, as the personal-contact service sectors of the economy ground to a halt in the wake of physical distancing becoming the norm.

Primary credit rate: On 15 March, the Federal Reserve announced that it would lower the primary credit rate by 150 basis points to $0.25 \%$. This was an aggressive move by the central bank, as the discount rate was now equal to the overnight rate, aiming to remove the stigma that is associated with tapping the Federal Reserve's discount window.

Bank requirements: On 15 March, the Federal Reserve eliminated reserve requirements, freeing up about US\$ 140 billion of capacity for banks to redeploy into other areas such as the repo market that had recently suffered from a lack of capacity. On 23 March, the Federal Reserve amended the treatment of the total loss-absorbing capacity (TLAC) that the eight United States global systemically important banks and designated foreign banks, which United States operations are required to have, to encourage banks to use their capital and liquidity buffers to support the economy during the COVID-19 pandemic.

Swap lines: On 15 March, the Federal Reserve, the Bank of Canada, the Bank of England, the Bank of Japan, the European Central Bank (ECB) and the Swiss National Bank announced coordinated action to enhance the provision of liquidity through the standing United States dollar liquidity swap line arrangements. These swap lines effectively provide global central banks with access to dollars in exchange for their own currency.

On 19 March, the Federal Reserve extended the swap lines to additional countries. The Federal Reserve said the new swap lines - lasting at least six months - would provide US\$ 60 billion each in dollar liquidity for the central banks of Australia, Brazil, the Republic of Korea, Mexico, Singapore and Sweden, as well as US\$ 30 billion each for the central banks of Denmark, Norway and New Zealand.

Repo market: The Federal Reserve has vastly expanded the scope of its repo operations to funnel cash to money markets. It is essentially offering an unlimited supply of money. On 16 March, after signs of strain emerged despite the emergency measures taken on the previous day, the Federal Reserve further expanded its intervention in short-term funding markets. ${ }^{\text {a }}$ The New York arm of the central bank said it would be willing to provide an additional US\$ 500 billion in overnight funding in the repo market, where investors swap high-quality collateral, such as Treasury notes, for cash.

Commercial Paper Funding Facility (CPFF): The Federal Reserve also gave the corporate sector of the United States a direct lifeline on 17 March, by announcing that it would begin buying commercial paper through a facility last used during the 2008-2009 financial crisis. On 23 March, the Federal Reserve announced that CPFF would be open to high-quality debt issued by municipalities. The Federal Reserve established the new facility under section 13(3) of the Federal Reserve Act, meaning it is acting with the approval of Steven Mnuchin, the United States Treasury Secretary. The last commercial paper facility from the global financial crisis was closed in 2010

Primary Dealer Credit Facility (PDCF): On 17 March, the Federal Reserve also took aggressive new action to shore up liquidity in financial markets, by allowing approved dealers in government debt, including the largest banks, to borrow cash against some stocks, municipal debt and higher-rated corporate bonds. The move, which revived a tool used during the last financial crisis, highlighted the Federal Reserve's concern for the health of short-term funding markets, which had been thrown into chaos by the pandemic

PDCF offers overnight and term funding with maturities up to 90 days and became available on 20 March 2020 . It will be in place for at least six months and may be extended as needed. Credit extended to primary dealers under this facility may be collateralized by a broad range of investment-grade debt securities, including commercial paper and municipal bonds, and a broad range of equity securities. The interest rate charged will be the primary credit rate, or discount rate, at the Federal Reserve Bank of New York.

Money Market Mutual Fund Liquidity Facility (MMLF): This Facility (launched on 18 March) makes loans available to eligible financial institutions, backed by high-quality assets purchased by the institutions from money-market mutual funds. On 20 March, the Federal Reserve expanded MMLF to include certain municipal money-market funds and, on 23 March, it said it would include a wider range of securities, including municipal variable-rate demand notes and bank certificates of deposit

The facility was the third announced by the Federal Reserve in a week and was created by citing emergency powers to extend credit, following earlier efforts to backstop the market for short-term commercial debt and to expand lending to the large financial institutions known as primary dealers, which function as the Federal Reserve's exclusive counterparties in markets Those facilities required the approval of the Treasury Secretary, Steven Mnuchin. The Federal Reserve said it would receive US\$ 10 billion from the Treasury to cover potential losses from its Exchange Stabilization Fund (ESF)

Term Asset-Backed Securities Loan Facility (TALF): On 23 March, the Federal Reserve announced the relaunch of another financial crisis-era facility. TALF was used by the Federal Reserve in 2008 to support consumer and business credit markets. The facility gives the Federal Reserve the ability to buy securities backed by student, car and credit-card loans, as well as lending to businesses through the Small Business Administration.

Primary Market Corporate Credit Facility (PMCCF): On 23 March, the Federal Reserve also announced the launch of this new facility. Created to support new bond and loan issuance, PMCCF will lend to investment-grade companies and provide bridge financing of four years 
Secondary Market Corporate Credit Facility (SMCCF): Another new facility was announced on 23 March. Created to provide liquidity for outstanding corporate bonds, this facility will buy corporate bonds issued by highly rated companies and United States-listed exchange-traded funds in the investment-grade corporate bond market.

TALF, PMCCF and SMCCF were designed to support US\$ 300 billion in new financing, and the Department of the Treasury will cover US\$ 30 billion in losses.

Repo facility for foreign and international monetary authorities (FIMA repo facility): On 31 March, the Federal Reserve announced the establishment of the FIMA Repo Facility, which, together with the United States dollar liquidity swap lines, is intended to help ease strains in global United States dollar funding markets. The facility allows FIMA account holders - central banks and other international monetary authorities with accounts at the Federal Reserve Bank of New York - to enter into repurchase agreements with the Federal Reserve to temporarily exchange United States Treasuries for dollars. It will be available for six months.

Relaxing regulatory requirement: On 1 April, the Federal Reserve moved to exclude United States Treasury securities and deposits at Federal Reserve Banks from the supplementary leverage ratio (SLR) until 31 March 2021. This decision was made to address the rise in reserves and deterioration in liquidity conditions in the Treasury market. The statement said that "the Board is providing the temporary exclusion in the interim final rule to allow banking organizations to expand their balance sheets as appropriate to continue to serve as financial intermediaries, rather than to allow banking organizations to increase capital distributions, and will administer the interim final rule accordingly".

On 9 April, the Federal Reserve announced both new measures and an expansion of existing measures with the goal to provide up to US\$ 2.3 trillion in loans to support the economy:

Paycheck Protection Program Liquidity Facility (PPPLF): extends credit to eligible financial institutions that originate PPP loans, taking the loans as collateral at face value. It bolsters the effectiveness of the Small Business Administration's Paycheck Protection Program (PPP) c by supplying liquidity to participating financial institutions through term financing backed by PPP loans to small businesses.

Main Street Lending Program: ensures credit flows to small and medium-sized businesses with the purchase of up to US\$ 600 billion in loans. The Department of the Treasury, using funding from the Coronavirus Aid, Relief, and Economic Security Act (CARES Act) will provide US\$ 75 billion in equity to the facility.

Primary and Secondary Market Corporate Credit Facilities (PMCCF and SMCCF) and the Term Asset-Backed Securities Loan Facility (TALF): the size and scope of all three facilities were expanded to increase the flow of credit to households and businesses through capital markets. These three facilities will now support up to US\$ 850 billion in credit, backed by US\$ 85 billion in credit protection provided by the Treasury. One notable change to PMCCF is that the Federal Reserve will purchase high-yield debt. it will be able to purchase debts of firms that were rated investment grade on 22 March but were subsequently downgraded to belowinvestment grade (providing they remain at least BB-/Ba3 rated) as well as high-yield corporate bond exchange-traded funds (ETFs).

Municipal Liquidity Facility (MLF): offers up to US\$ 500 billion in lending to states and municipalities. The Treasury will provide US\$ 35 billion of credit protection for MLF using funds appropriated by the CARES Act, which is discussed in the next section.

On 27 April, the Federal Reserve Board announced an expansion of the scope and duration of the Municipal Liquidity Facility to add new population thresholds that allow substantially more entities to borrow directly from the MLF than the initial plan announced on 9 April.

On 30 April, the Federal Reserve announced the expansion of the scope and eligibility for the Main Street Lending Program. The changes included: creating a third loan option, with increased risk sharing by lenders for borrowers with greater leverage; lowering the minimum loan size for certain loans to US\$ 500,000; and expanding the pool of businesses eligible to borrow. On 16 June, the Federal Reserve said it was studying how to expand the Main Street Lending Program to include non-profit organizations.

On 16 June, SMCCF was expanded beyond the purchase of exchange-traded funds, as part of a continued effort to support financial markets and ease credit conditions. The Federal Reserve announced that it was starting purchases of individual corporate bonds through the facility.

On 28 July, the Federal Reserve announced the extension to 31 December of seven programs set to expire on or around 30 September, including PDCF, MMLF, PMCCF, SMCCF, TALF, PPPLF and the Main Street Lending Program.

On 29 July, the Federal Reserve announced the extensions of its temporary dollar liquidity swap lines and the temporary repurchase agreement facility for foreign and international monetary authorities (FIMA repo facility) through 31 March 2021.

Source: Economic Commission for Latin America and the Caribbean (ECLAC), on the basis of data from the United States Federal Reserve, Department of the Treasury and other official figures.

As early as last autumn, the Federal Reserve had been injecting liquidity into the system in an effort to address some liquidity issues arising from instability in the repo markets last year. The Federal Reserve announced in its January 2020 interest rate decision that it would be involved in the repo market until at least April 2020. As a result, the Open-Market Desk expanded its overnight and term repo operations to improve market liquidity.

These measures, through programs under section 13(3) of the Federal Reserve Act, will intermediate around US\$195 billion of the US\$ 454 billion that was appropriated by the United States Congress in the Coronavirus Aid, Relief, and Economic Security Act (CARES Act), which will be discussed in the section on fiscal policy.

PPP provides loans to small businesses so that they can keep their workers on the payroll and is part of Phase 3 of the fiscal measures passed by Congress, which are discussed in the section on fiscal policy. 


\section{Old and new tools}

The Federal Reserve has also opened its discount window to commercial banks, lowered the primary credit rate by 150 basis points to $0.25 \%$, eliminated reserve requirements, re-established dollar liquidity swap line arrangements, and expanded repurchase agreement (repo) operations. It has also reintroduced old facilities used during the global financial crisis and created new ones, to support the flow of credit, in some cases backed by the United States Treasury (see box 1).

These facilities include: (i) the Commercial Paper Funding Facility (CPFF) to facilitate the issuance of commercial paper by companies and municipalities; (ii) the Primary Dealer Credit Facility (PDCF) to shore up liquidity in financial markets, by allowing approved dealers in government debt to borrow cash against some stocks, municipal debt, and higher-rated corporate bonds; (iii) the Money Market Mutual Fund Liquidity Facility (MMLF) to make loans available to eligible financial institutions backed by high-quality assets purchased by the institutions from money market mutual funds, including municipal variable-rate demand notes and bank certificates of deposit; (iv) the Term Asset-Backed Securities Loan Facility (TALF), which gives the Federal Reserve the ability to buy securities backed by student, car and credit-card loans, as well as loans to businesses through the Small Business Administration (SBA); (v) the Primary Market Corporate Credit Facility (PMCCF) to purchase new bonds and loans from companies; (vi) the Secondary Market Corporate Credit Facility (SMCCF) to provide liquidity for outstanding corporate bonds; (vii) the Repurchase Agreement Facility for Foreign and International Monetary Authorities (FIMA Repo Facility), which, together with the United States dollar liquidity swap lines, is intended to help ease strains in global United States dollar funding markets; (viii) the Paycheck Protection Program Liquidity Facility (PPPLF) to provide liquidity to participating financial institutions that provide loans to small businesses under the SBA Paycheck Protection Program (PPP); (ix) the Main Street Lending Program to ensure credit flows to small and mid-sized businesses with the purchase of up to US\$ 600 billion in loans; and $(x)$ the Municipal Liquidity Facility (MLF), which offers lending to states and municipalities.

Although the Federal Reserve has limited ability to buy assets and make loans, under emergency conditions, and with the permission of the Treasury Secretary (pursuant to section 13(3) of the Federal Reserve Act), it can add more lending facilities to ensure that businesses can borrow cheaply and effectively in order to weather crises. The central bank has not only relaunched facilities created during the 2008-2009 financial crisis but has also created five new facilities in response to the pandemic (see table 2).

Table 2

New and old Federal Reserve facilities used in response to the pandemic

\begin{tabular}{|c|c|}
\hline New facilities & Old facilities \\
\hline PMCCF & CPFF \\
\hline SMCCF & PDCF \\
\hline FIMA & MMLF \\
\hline PPPLF & TALF \\
\hline MLF & \\
\hline
\end{tabular}

Source: Economic Commission for Latin America and the Caribbean (ECLAC), on the basis of data from the Federal Reserve.

Note: Old facilities are tools used in response to the 2008-2009 financial crisis.

In broad terms, the intended goal of these facilities and measures taken by the Federal Reserve is to support financial market functioning, encourage banks to lend, support corporations and businesses, support households and consumers, support state and municipal borrowing, and cushion United States money markets from international pressures (see table 3). 
Table 3

New and old Federal Reserve facilities and measures, by objective

\begin{tabular}{|c|c|}
\hline \multirow[t]{4}{*}{ 1. Supporting financial market functioning } & Securities purchases (quantitative easing) - open ended \\
\hline & Lending to securities firms: PDCF \\
\hline & Backstopping money market mutual funds: MMLF \\
\hline & Repo operations \\
\hline \multirow[t]{2}{*}{ 2. Encouraging banks to lend } & Direct lending to banks (discount window) \\
\hline & $\begin{array}{l}\text { Relaxing regulatory requirements: reserve requirements, total loss-absorbing capacity (TLAC) } \\
\text { and supplementary leverage ratio (SLR) }\end{array}$ \\
\hline \multirow[t]{3}{*}{ 3. Supporting corporations and businesses } & Direct lending to major employers: PMCCF, SMCCF \\
\hline & Supporting the commercial paper market: CPFF \\
\hline & Supporting loans to small and medium-sized businesses: PPPLF, Main Street Lending Program \\
\hline 4. Supporting households and consumers & TALF \\
\hline \multirow[t]{2}{*}{ 5. Supporting state and municipal borrowing } & Direct lending: MLF \\
\hline & Supporting bond liquidity: using the MMLF and the CPFF to backstop municipal debt markets \\
\hline \multirow[t]{2}{*}{ 6. Relieving international pressures } & Swap lines \\
\hline & FIMA, which offers dollars to central banks that do not have an established swap line \\
\hline
\end{tabular}

Source: Economic Commission for Latin America and the Caribbean (ECLAC), on the basis of data from the Federal Reserve and J. Cheng, D. Skidmore and D. Wessel, "What's the Fed doing in response to the COVID-19 crisis? What more could it do?", The Brookings Institution, 9 April 2020 [online] https://www.brookings.edu/research/fed-response-to-covid19/.

\section{B. Fiscal policy}

As in the case of monetary policy, the speed with which fiscal measures have been implemented has been unprecedented. It took over 500 days for all the fiscal measures to take effect during the global financial crisis. This time, in response to the pandemic, the United States Congress passed three laws in the month of March alone (figure 15).

Figure 15

Total funds authorized by the United States Congress, 2008-2009 and 2020

(Billions of dollars)

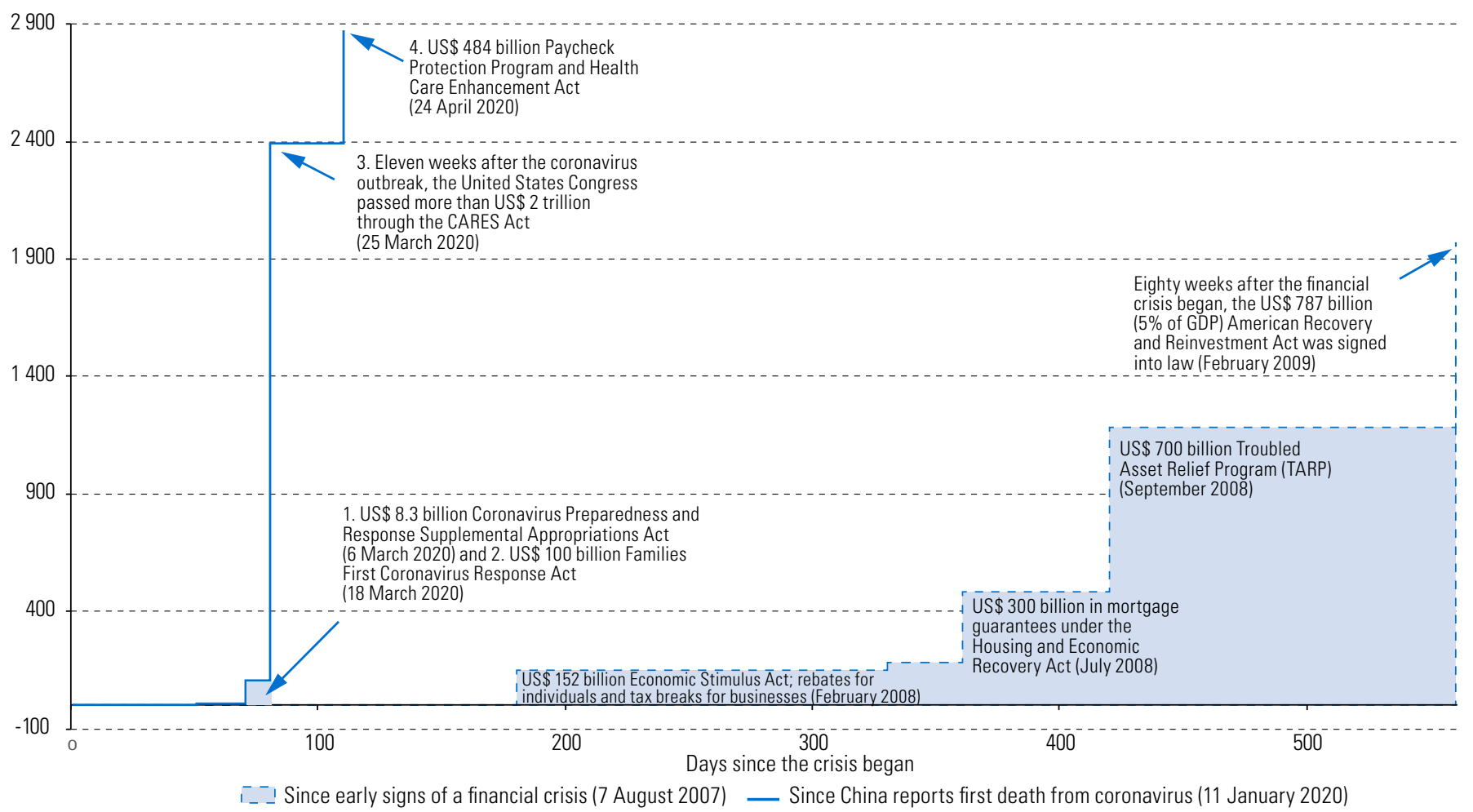

Source: Economic Commission for Latin America and the Caribbean (ECLAC), on the basis of Congressional Budget Office and other official estimates, and J. M. Schlesinger and H. Sender, "How fast the economy crashed and Washington responded -in charts", Wall Street Journal, 27 March 2020 [online] https://www.wsj.com/articles/how-fast-the-economy-crashed-and-washington-respondedin-charts-11585334137. Note: The first signs of the financial crisis emerged in August 2007, when securities backed by subprime mortgages plummeted. 
Congress has passed five pieces of stimulus legislation in response to COVID-19: three fiscal packages and two supplementary measures. Together, they are equivalent to $13 \%$ of GDP.

\section{Phase One: Coronavirus Preparedness and Response Supplemental Appropriations Act, 6 March 2020}

The first phase comprised US\$ 8.3 billion in emergency spending for federal agencies fighting the spread of the disease, including US\$ 3.4 billion for the Public Health and Social Services Emergency Fund to research and develop new vaccines, therapeutics and diagnostics; US\$ 1.9 billion for the Centers for Disease Control and Prevention (CDC) to back up state and local government response efforts; and US\$ 1.6 billion in international assistance.

\section{Phase Two: Families First Coronavirus Response Act, 18 March 2020}

This second major piece of legislation provided paid sick leave, food assistance for vulnerable populations and financial help for coronavirus testing. It provided free testing for COVID-19 for all and required smaller employers to provide at least two weeks of paid sick leave to many of those affected by the crisis. It also increased Medicaid funding, expanded unemployment insurance and provided more money for food stamps, in an effort to provide a basic safety net as layoffs and COVID-19 cases begin to impact every state. Financial assistance mobilized under phase one and two together was equivalent to $0.5 \%$ of GDP

\section{Phase Three: Coronavirus Aid, Relief, and Economic Security (CARES) Act, 27 March 2020}

This Act is referred to by lawmakers as "Phase 3" of Congress's coronavirus response, following the Coronavirus Preparedness and Response Supplemental Appropriations Act (6 March 2020) and the Families First Coronavirus Response Act (18 March 2020). This third phase was about mitigating the damage inflicted by the pandemic.

The legislation included more than US\$ 2 trillion (around 11\% of GDP) in new spending and tax relief, making it the largest rescue package in United States history. Key provisions of the CARES Act include: (i) US\$290 billion to provide one-time checks to individuals; (ii) US\$2 260 billion to expand unemployment benefits; (iii) US\$2 25 billion in food assistance; (iv) US\$ 510 billion to prevent corporate bankruptcy by providing loans and loan guarantees, and backstopping the Federal Reserve 13(3) program; (v) US\$ 367 billion in forgivable SBA loans and guarantees to help small businesses that retain workers; (vi) US\$ 180 billion for hospitals and health care; (vii) US\$150 billion in transfers to state and local governments; (viii) over US\$ 100 billion in funding for education, transit systems and international assistance; and (ix) US\$ 280 billion in tax cuts, deferrals and delays (see diagram 1 and box 2)

\section{Diagram 1}

Phase three stimulus: over US\$ 2 trillion

(Billions of dollars)

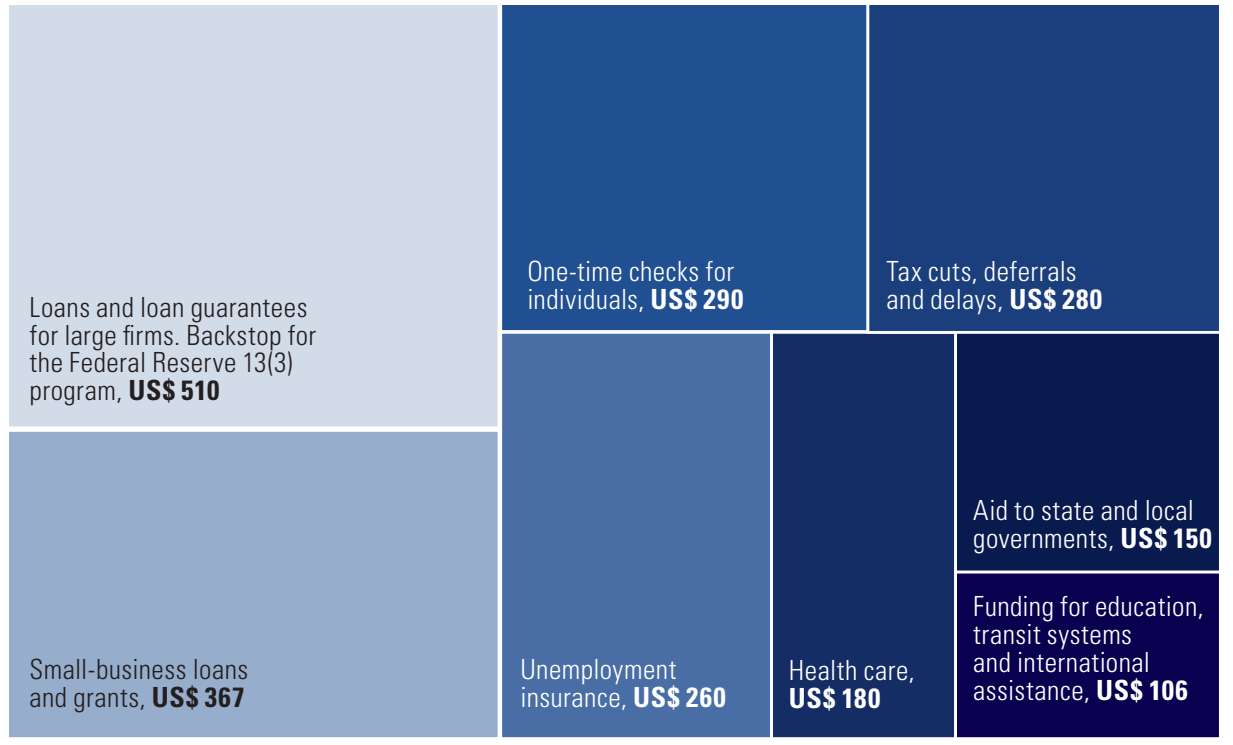

Source: Economic Commission for Latin America and the Caribbean (ECLAC), on the basis of International Monetary Fund (IMF) and Moody's Analytics estimates. 
Box 2

Coronavirus Aid, Relief, and Economic Security (CARES) Act, 27 March 2020

The main provisions of the CARES Act include:

\section{Measures to support households}

Cash payments: roughly US\$300 billion in total. The Act provides for direct payments of US\$1,200 per adult (plus US\$500 per child) for those with gross annual income of less than US $\$ 75,000$ (US\$150,000 for a couple filing jointly). The direct grants are phased out for upper-income brackets, and are not available for individuals without children earning over US\$99,000 a year, or married couples without children earning over US\$198,000 per year. Payments are structured as tax refunds to allow the Internal Revenue Service (IRS) to distribute the funds quickly.

Unemployment assistance: US\$ 260 billion to expand eligibility for state unemployment insurance programs for workers, including the self-employed, who are adversely affected by COVID-19 (including those with a sick family member or a child that is unable to attend school). Benefits will be provided for up to four months (until 31 July). The CARES Act extends benefits to 29 weeks, from 26 weeks in most states and provides, in addition, a supplemental payment of US\$ 600 per week for those eligible for assistance.

Food assistance: US\$ 25 billion for child nutrition programs and additional funding for Supplemental Nutrition Assistance Program (SNAP) food stamps.

Distributions from tax-advantaged retirement funds: Individuals will be allowed to make a coronavirus-related distribution of up to US\$100,000 without penalty.

Tax delay: Deadlines for individuals filing tax returns were deferred from April to July

\section{Measures to support businesses}

Assistance to severely distressed sectors: over US\$ 500 billion for loans, loan guarantees or other aid to businesses -including the possibility for the government to take direct equity stakes in distressed companies. The assistance includes US\$ 25 billion for passenger air carriers, US\$ 4 billion for cargo air carriers, US\$ 17 billion for businesses deemed critical to national security, and the remainder to backstop section 13(3) Federal Reserve facilities that purchase corporate obligations in primary or secondary markets (US\$ 454 billion).

Companies receiving direct loans or loan guarantees will be asked to limit executive compensation to US\$ 425,000 per year and not undertake share buybacks for at least one year. Businesses owned by the President, Vice President, members of Congress, or heads of federal agencies will be ineligible for support. This corporate assistance will be overseen by an independent inspector general and a congressional oversight panel.

Assistance to small businesses (Paycheck Protection Program (PPP)): roughly US\$ 367 billion in SBA loans and guarantees to companies with up to 500 employees (including independent contractors and the self-employed) to cover payroll costs, mortgage and rent payments, utilities and health benefits. Emergency advances are to be provided on these loans within three days of the application and the total loan can be up to $250 \%$ of monthly payroll. The loans will be eligible for partial or total forgiveness depending on the extent to which the firm retains its pre-crisis number of employees on payroll.

Payroll tax deferral: Firms will be allowed to defer their payroll tax obligations for the remainder of the year (which would be paid in instalments in 2021/22)

Employee retention tax credit: This credit will provide incentives to businesses to keep workers on their payrolls.

Delay in tax deadlines: Businesses can delay making their quarterly estimated tax payments until after 15 October 2020 and defer payroll tax payments until the end of the year.

\section{Other provisions}

US\$ 180 billion for health-care spending: Of that money, US\$100 billion will fund hospitals and providers hit hardest by the outbreak, which could be used to purchase PPE for health-care workers and testing supplies, and to finance emergency operation centres. The legislation increases funding for community health centres; Medicare payments; telehealth and home service; and public health agencies. The Act also includes a range of measures to address current medical supply shortages and prevent future scarcity (including through the Defense Production Act)

US\$ 150 billion in transfers to state and local governments to address spending shortfalls related to the pandemic, distributed according to population size. A municipality may apply to receive aid directly, reducing the amount available to the rest of the state.

US\$ $\mathbf{5 0}$ billion for international assistance.

US\$ 31 billion in education funding to support local schools and colleges, and more flexible treatment of financial aid and student loans.

US\$ $\mathbf{2 5}$ billion for transit systems to make up for revenue lost because of dwindling passenger numbers.

Source: Economic Commission for Latin America and the Caribbean (ECLAC), on the basis of International Monetary Fund (FMI) and Moody's Analytics estimates. 
The magnitude of the pandemic has strained United States domestic resources, while also putting pressure on international assistance. Although most of the CARES Act is devoted to the domestic response and relief, it also includes some supplemental foreign aid funding and pending authorizations for international financial institutions to support the international response. There is also foreign aid funding provided as part of the initial supplemental legislation (see box 3).

\section{Box 3}

Foreign aid funds

According to data from the Congressional Research Service (CRS), the United States Congress has appropriated almost US $\$ 1.8$ billion in emergency foreign assistance funds through two supplemental appropriations bills to address the impact of COVID-19. The first round of supplemental aid funding (Public Law 116-123, signed into law on 6 March, part of the Coronavirus Preparedness and Response Supplemental Appropriations Act) focused on replenishing emergency health and disaster assistance funds that had already been depleted by COVID-19 response activities. It also included funds for "economic, security and stabilization requirements" related to the pandemic. The second supplemental appropriations bill with foreign assistance funding (Public Law 116-136, signed into law on 27 March, part of the CARES Act) provided additional COVID-19 and foreign assistance. "With a whole-of-government initiative under way to address the pandemic in the United States, Congress is continuously assessing whether funds should support pandemic response overseas, or if such resources should be focused on response needs in the United States" (Brown, Lawson and Morgenstern, 2020).

Source: Economic Commission for Latin America and the Caribbean (ECLAC), on the basis of information from the Congressional Research Service (CRS) and N. Brown, M. Lawson and E. Morgenstern, "COVID-19 and foreign assistance: issues for Congress", In Focus, No. 11496,

Congressional Research Service (CRS), 6 April, 2020.

Congress also passed new legislation in April and June to improve the effectiveness of the programs included in the previous three fiscal packages, and the Paycheck Protection Program (PPP) in particular. On 24 April 2020, the Paycheck Protection Program and Health Care Enhancement Act was signed into law. The bill injected an additional US\$ 484 billion into coronavirus relief efforts. It included: (i) US\$ 322 billion in additional funding for PPP, the small-business loan program that quickly reached its previous cap, including US\$ 60 billion to be specifically set aside for small, medium-sized and community lenders; (ii) US\$ 60 billion for small-business disaster loans and grants (the Economic Injury Disaster Loan fund); (iii) US\$ 75 billion for hospitals; and (iv) US\$ 25 billion for coronavirus testing

The Paycheck Protection Program Flexibility Act, which was signed into law on 5 June 2020, amends the CARES Act's Paycheck Protection Program (PPP) to give borrowers more freedom in how and when loan funds are spent while retaining the possibility of full forgiveness. The main changes include: an increase to 24 weeks to spend loan proceeds, up from 8 weeks; a reduction in mandatory payroll spending from $75 \%$ to 60\%; two new exceptions let borrowers obtain full forgiveness even without fully restoring their workforce; the time to repay the loan was extended to five years from the original two; and the new measure allows businesses to delay paying payroll taxes even if they took out a PPP loan. ${ }^{9}$

Important deadlines are looming, however, with programs due to run out in the coming weeks and months. Extra unemployment benefits (the CARES supplemental payment of US\$ 600 per week), for example, expire on 31 July 2020. Each expiration date will test the still-fragile recovery. It is now up to lawmakers to decide how much more stimulus the United States economy might need moving forward, and what form it should take.

Two months after it started, PPP has directed more than US\$ 530 billion to 4.5 million companies, and it is widely believed to have had a stabilizing impact on the United States economy. 


\section{Longer-term challenges}

- What kind of post-COVID economic recovery will take place? There is extreme uncertainty regarding the timing and shape of the economic recovery: V-, U-, L-shaped or some other shape. The recovery will likely depend on the duration of the crisis. In the words of the former Chair of the Federal Reserve, Ben Bernanke, "the critical factor in terms of how bad this [the pandemic crisis] is going to be, how much imprint it will leave on the [United States] economy, is its duration - how long will it last. The longer it lasts the more existing businesses will fail financially, will close their doors. The longer it lasts, the more people will lose their jobs and lose their association with their former employers. The longer it lasts, the more destruction there will be and the harder it will be to come back. So the duration is going to be critical. The most important determinant of the duration is the public health response" (The Brookings Institution, 2020). In the Semiannual Monetary Policy Report to Congress on 16 June, the current Chair of the Federal Reserve Jerome Powell added that the biggest factor weighing on the outlook was "uncertainty about the path of the disease and the effects of measures to contain it" (Board of Governors of the Federal Reserve System, 2020b).

- From addressing an emergency to supporting a recovery. The Federal Reserve has acted promptly and forcefully, as the first line of defence for liquidity and keeping markets orderly. Its balance sheet has expanded rapidly since March as it has implemented openended quantitative easing to buy as many Treasuries and mortgage-backed securities as necessary. However, the Federal Reserve's toolkit -including interest rates that are already very low - is more limited for stimulating growth. The Federal Reserve is the lender of last resort, but has no control over fiscal spending. According to the Chair of the Federal Reserve the government may need to spend more to support the economy's recovery from the coronavirus-induced contraction and to prevent household and business insolvencies, which could weigh on growth for years to come. Though costly, the Chair has said that added stimulus would be worthwhile if it helped avoid long-term economic damage as a result of the COVID-19 crisis. Moreover, Mr. Powell stressed in his June remarks to Congress that the burden of the COVID-19 downturn had "not fallen equally on all Americans", with a disproportionate impact on low-income households. "If not contained and reversed, the downturn could further widen gaps in economic well-being that the long expansion had made some progress in closing," he said.

- Does the rising debt burden matter? As a result of the pandemic and measures to address its economic effects, the federal deficit and debt are projected to be significantly larger. The Congressional Budget Office projects that federal debt held by the public will be $101 \%$ of GDP by the end of fiscal year 2020 and grow to $108 \%$ of GDP at the end of 2021, compared with $79 \%$ at the end of fiscal year 2019. While the general view is that this is the price that must be paid to address the impact of COVID-19, and that low interest rates mean that a higher level of debt might be sustainable, a rising debt burden could pose significant medium- and longer-term challenges, including intergenerational tensions

- Has resilience been sacrificed too much for efficiency? The COVID-19 pandemic has revealed critical supply chain vulnerabilities in key sectors of the global economy, including the medical supply chain. As authorities and industries assess the benefits and costs of globalized supply chains, and whether they have become overly exposed to a few suppliers, various ways of building resilience might be pursued. The diversification and onshoring of supply chains appear to be plausible options. 


\section{Bibliography}

Adrian, T. and F. Natalucci (2020), "COVID-19 crisis poses threat to financial stability", IMFBlog, 14 April [online] https://blogs.imf.org/2020/04/14/covid-19-crisis-poses-threat-tofinancial-stability/.

Automotive News (2020), "Mexico asks U.S., Canada to grant automakers transition for USMCA rules", 6 April [online] https://www.autonews.com/automakers-suppliers/mexico-asksus-canada-grant-automakers-transition-usmca-rules.

BLS (United States Bureau of Labor Statistics) (2020a), The Employment Situation - April 2020, Washington, D.C.

(2020b), The Employment Situation - May 2020, Washington, D.C.

(2020c), The Employment Situation - June 2020, Washington, D.C.

(2020d), "Current Employment Statistics" [online] https://www.bls.gov/ces/.

Board of Governors of the Federal Reserve System (2020a), "Industrial production and capacity utilization", Federal Reserve Statistical Release, Washington, D.C.

(2020b), "Semiannual Monetary Policy Report to the Congress", Washington, D.C., 16 June [online] https://www.federalreserve.gov/newsevents/testimony/powell20200616a.htm.

Borjas, G. J. and H. Cassidy (2020), "The adverse effect of the COVID-19 labor market shock on immigrant employment", Discussion Paper Series, No. 13277, Bonn, Institute for Labor Economics (IZA), May.

Bown, C. P. (2020), "COVID-19: Trump's curbs on exports of medical gear put Americans and others at risk", Peterson Institute for International Economics, 9 April [online] https:// www.piie.com/blogs/trade-and-investment-policy-watch/covid-19-trumps-curbs-exportsmedical-gear-put-americans-and.

Brinca, P., J. B. Duarte, M. Faria e Castro (2020), "Is the COVID-19 pandemic a supply or a demand shock?", Economic Synopses, No. 31, Federal Reserve Bank of St. Louis.

Brown, N., M. Lawson and E. Morgenstern (2020), "COVID-19 and foreign assistance: issues for Congress", In Focus, No. 11496, Congressional Research Service (CRS), 6 April.

CBP (United States Customs and Border Protection) (2019), "U.S. Border patrol southwest border apprehensions by sector fiscal year 2019: southwest border unaccompanied alien children (0-17 yr old) apprehensions", 14 November [online] https://www.cbp. gov/newsroom/stats/sw-border-migration/usbp-sw-border-apprehensions-fy2019 [accessed on: 14 August 2020].

Cheng, J., D. Skidmore and D. Wessel (2020), "What's the Fed doing in response to the COVID-19 crisis? What more could it do?", The Brookings Institution, 9 April [online] https://www.brookings.edu/research/fed-response-to-covid19/.

ECLAC (Economic Commission for Latin America and the Caribbean) (2020), "Restrictions on the export of medical products hamper efforts to contain coronavirus disease (COVID-19) in Latin America and the Caribbean", COVID-19 Reports, Santiago, May.

FAO (Food and Agriculture Organization of the United Nations) (2020), Migrant workers and the COVID-19 pandemic, Rome, 7 April.

Gagnon, J. (2020), "COVID-19: consequences for international migration and development", Development Matters, Organization for Economic Cooperation and Development (OECD), 2 April [online] https://oecd-development-matters.org/2020/04/02/covid-19consequences-for-international-migration-and-development/.

García Mora, A. and M. Rutkowski (2020), "Remittances in times of the coronavirus - keep them flowing", Private Sector Development Blog, World Bank, 3 April [online] https:// blogs.worldbank.org/psd/remittances-times-coronavirus-keep-them-flowing.

González, A. (2020), "Yes, medical gear depends on global supply chains. Here's how to keep them moving", Peterson Institute for International Economics, 27 March [online] https:// www. piie.com/blogs/trade-and-investment-policy-watch/yes-medical-gear-dependsglobal-supply-chains-heres-how-keep.

Inter-American Dialogue (2020), "Impact of the COVID-19 pandemic on migrants and remittances to Latin America and the Caribbean", 13 April [online] https://www.thedialogue.org/ analysis/impact-of-the-covid-19-pandemic-on-migrants-and-remittances-to-latinamerica-and-the-caribbean/.

NBER (National Bureau of Economic Research) (2020), "The NBER's Recession Dating Procedure" [online] https://www.nber.org/cycles/recessions.pdf.

Ocampo, J. A. (2020), "Economías emergentes: hoja de ruta para manejar financiamiento y deuda", El Tiempo, 7 June [online] https://www.eltiempo.com/mundo/economiasemergentes-hoja-de-ruta-para-manejar-financiamiento-y-deuda-en-los-paisesemergentes-504170. 
Reinsch, W., J. Caporal and S. Tuljapurka (2020), "Trade symptoms of the pandemic", Center for Strategic and International Studies (CSIS), 3 April [online] https://www.csis. org/analysis/trade-symptoms-pandemic.

Reuters (2020), "Mexico auto production, exports nosedive as coronavirus bites", 6 April [online] https://www.reuters.com/article/mexico-autos-idUSL1N2BU16P.

Richter, F. (2020), "Economic impact of COVID-19: U.S. car industry most reliant on Chinese parts", 21 February [online] https://www.statista.com/chart/20913/chinese-exports-ofmotor-vehicle-parts-and-accessories/.

Rogoff, K. (2020), "Mapping the COVID-19 recession", Project Syndicate, 7 April.

Schlesinger, J. M. and H. Sender (2020), "How fast the economy crashed and Washington responded -in charts", Wall Street Journal, 27 March [online] https://www.wsj.com/ articles/how-fast-the-economy-crashed-and-washington-respondedin-charts-11585334137.

Sutter, K., M. Sutherland and A. Schwarzenberg (2020), "COVID-19: China medical supply chains and broader trade issues", CRS Report, No. R46304, Congressional Research Service (CRS), 6 April

The Brookings Institution (2020), "Webinar: Former Fed Chair Ben Bernanke weighs in on the economic response to COVID-19", Washington, D.C., 7 April [online] https://www. brookings.edu/events/webinar-former-fed-chair-ben-bernanke-weighs-in-on-theeconomic-response-to-covid-19/.

The Economic Club of New York (2020), "Ambassador Robert Lighthizer: United States Trade Representative", 4 June [online] https://www.econclubny.org/documents/10184/109144/ 2020LighthizerTranscript.pdf.

United Nations (2020), UN Comtrade Database [online] https://comtrade.un.org/ [accessed on: 14 August 2020].

United States Census Bureau (2020), "Advance monthly sales for retail and food services, July 20", United States Census Bureau [online] https://www.census.gov/retail/marts/ www/marts_current.pdf.

UNWTO (World Tourism Organization) (2020), UNWTO Tourism Data Dashboard [online database] https://www.unwto.org/es/unwto-tourism-dashboard [accessed on: 20 June].

USDA (United States Department of Agriculture) (2020), "USDA announces Coronavirus Food Assistance Program", Press Release, No. 0222.20, 17 April [online] https://www.usda.gov/ media/press-releases/2020/04/17/usda-announces-coronavirus-food-assistance-program.

White, D. and B. Yaros (2020), "A stimulus to remember", Moody's Analytics, 30 March [online] https://www.economy.com/economicview/analysis/378887/A-Stimulus-to-Remember.

World Bank (2020), "World Bank predicts sharpest decline of remittances in recent history", 22 April [online] https://www.worldbank.org/en/news/press-release/2020/04/22/ world-bank-predicts-sharpest-decline-of-remittances-in-recent-history.

WTO (World Trade Organization) (2020), "Trade set to plunge as COVID-19 pandemic upends global economy", Press Release, No. 855, 8 April [online] https://www.wto.org/english/ news_e/pres20_e/pr855_e.htm.

Zarroli, J. and A. Schneider (2020), "Jobs carnage mounts: 17 million file for unemployment in 3 weeks", NPR, 9 April [online] https://www.npr.org/sections/coronavirus-liveupdates/2020/04/09/830216099/6-6-million-more-file-for-unemployment-ascoronavirus-keeps-economy-shut.

This document is part of a series of reports prepared by the Economic Commission for Latin America and the Caribbean (ECLAC) on the evolution and effects of the COVID-19 pandemic. It was prepared by the ECLAC office in Washington, D.C., directed by Inés Bustillo, under the general coordination of Alicia Bárcena, Executive Secretary, and Mario Cimoli, Deputy Executive Secretary of ECLAC.

Copyright (C) United Nations, 2020 